\title{
1 Winter-mixing preconditioning of the spring phytoplankton bloom in
}

\section{2 the Bay of Biscay}

3 Authors: Ricardo González-Gil ${ }^{1 *}$, Fernando González Taboada ${ }^{2,3}$, Carlos Cáceres ${ }^{4}$, John L.

4 Largier ${ }^{5}$, Ricardo Anadón ${ }^{1}$

$5 \quad *$ Contact author e-mail: rgonzalezgil@gmail.com

6 1. Área de Ecología, Dpto. Biología de Organismos y Sistemas, Universidad de Oviedo, C/Valentín Andrés Álvarez 7 s/n, E33071 Oviedo, Asturias, Spain.

8 2. Atmospheric and Oceanic Sciences, Princeton University, Princeton, NJ, USA.

9 3. Geophysical Fluid Dynamics Laboratory, National Oceanic and Atmospheric Administration, Princeton, NJ 1008540 USA.

11 4. Dept. of Mathematics and Statistics, University of Strathclyde, 26 Richmond St, Glasgow G1 1XQ, UK USA.

14 Running head: Winter mixing and spring bloom

15 Key words: winter mixing, spring phytoplankton bloom, time series, global warming, remote 16 sensing, Bay of Biscay 
19 The spring phytoplankton bloom plays a key role in the dynamics of temperate and

20 polar seas. Nevertheless, the mechanisms and processes behind these blooms remain a

21 subject of considerable debate. We analyzed the influence of deep mixing during winter

22 on the spring phytoplankton bloom in the Cantabrian Sea (southern Bay of Biscay). To

23 this end, we combined long-term physical and biogeochemical in situ data (1993-2012)

24 and satellite observations (1997-2012). Deeper winter mixing led to higher nitrate and

25 chlorophyll concentrations through the water column during the spring bloom. However,

26 this effect was modified by short-term variability in near-surface stratification in spring.

27 Winter-mixing preconditioning also influenced different spring bloom metrics: deeper 28 and later mixing in winter was followed by later blooms with a larger peak. In these 29 enhanced blooms, nitrate was taken up at faster rates, indicating higher rates of 30 phytoplankton production. Winters with weaker mixing (that led to weaker spring

31 blooms) were associated with warmer surface temperatures. This relationship suggests

32 that the multi-decadal trend towards warmer surface temperatures in the Bay of Biscay 33 may promote a decrease in the magnitude of the spring bloom, which could impact upper 34 trophic levels and also deep carbon export in the future.

This is the accepted version of the following article: González-Gil, R., González Taboada, F., Cáceres, C., Largier, J. L. and Anadón, R. (2017), Winter-mixing preconditioning of the spring phytoplankton bloom in the Bay of Biscay. Limnol. Oceanogr. doi:10.1002/Ino.10769, which has been published in final form at Limnology \& Oceanography. This article may be used for non-commercial purposes in accordance with the Wiley Self-Archiving Policy. 
Every year, the spring phytoplankton bloom reappears in temperate and polar seas, turning surface waters green. This phenomenon has fascinated researchers since the early days of oceanography in the $19^{\text {th }}$ century (Banse 1992; Fischer et al. 2014). In the last decades, satellite images of surface chlorophyll concentration led to a renewed interest in phytoplankton blooms by revealing their ubiquity and large spatial extent (Parsons and Lalli 1988; Yoder et al. 1993; McClain 2009). Vernal phytoplankton blooms pump important amounts of atmospheric carbon into deep oceanic waters, making them a key component of biogeochemical cycles (Longhurst and Harrison 1989; Falkowski et al. 1998; Sarmiento and Gruber 2006). At the same time, these blooms support much of the annual productivity at higher trophic levels, including many exploited species (Hjort 1914; Cushing 1990; Townsend et al. 1994).

The North Atlantic spring phytoplankton bloom is the most pronounced bloom in open ocean waters (Yoder et al. 1993), although its characteristics vary substantially in space and time (Ueyama and Monger 2005; Racault et al. 2012; González Taboada and Anadón 2014). Interannual changes in the timing and magnitude of phytoplankton blooms can lead to a trophic match-mismatch that modulates the survival of upper trophic levels, including commercially fished stocks (Cushing 1990; Platt et al. 2003; Durant et al. 2007; Koeller et al. 2009; Kristiansen et al. 2011). With such important impacts, there is a growing interest in understanding the factors that promote interannual variability in the characteristics of the spring phytoplankton bloom, especially in the context of global climate change (Racault et al. 2012). Different hypotheses have been proposed to explain the mechanisms that trigger the onset of spring blooms, leading to an intense and ongoing debate (Behrenfeld and Boss 2014; Lindemann and St. John 2014; Chiswell et al. 2015;

This is the accepted version of the following article: González-Gil, R., González Taboada, F., Cáceres, C., Largier, J. L. and Anadón, R. (2017), Winter-mixing preconditioning of the spring phytoplankton bloom in the Bay of Biscay. Limnol. Oceanogr. doi:10.1002/Ino.10769, which has been published in final form at Limnology \& Oceanography. This article may be used for non-commercial purposes in accordance with the Wiley Self-Archiving Policy. 
Ferreira et al. 2015). Most of the drivers involved in these mechanisms also influence the magnitude of the bloom (Follows and Dutkiewicz 2002; Henson et al. 2006; Henson et al. 2009).

Among the physical processes that influence bloom development, deep mixing in winter stands out due to its crucial role in preconditioning the environment for a phytoplankton bloom in the next spring. During winter, deep convective mixing leads to the replenishment of near-surface nutrients (Williams and Follows 2003). Inorganic nitrogen compounds, such as nitrate, are often limiting for phytoplankton productivity (Falkowski et al. 1998; Moore et al. 2013) and thus, their availability is an important factor controlling the development of spring blooms (see for example Sambrotto et al. 1986; Sieracki et al. 1993; D'Ortenzio et al. 2014). As winter progresses towards spring, nutrients in surface layers become isolated from deeper waters with the onset of seasonal stratification. This sets an upper bound on the amount of nutrients available for phytoplankton in spring because, for many species, the access to nutrients below the seasonal thermocline is very limited. Deep mixing also constrains phytoplankton growth and the density of seeding populations by reducing the residence time of individual phytoplankters in the euphotic layer (Sverdrup 1953), although it simultaneously decreases encounter rates with grazers due to dilution effects (Yoshie et al. 2003; Behrenfeld 2010; Behrenfeld and Boss 2014).

With such a variety of effects operating together, the question that arises is: how and to what extent does winter mixing influence the spring phytoplankton bloom? Several studies have investigated the role of winter mixing in determining the magnitude of spring 81 blooms (e.g. Follows and Dutkiewicz 2002; Henson et al. 2009; Martinez et al. 2011), but we are not aware of any analyses of how winter mixing affects other characteristics such and Anadón, R. (2017), Winter-mixing preconditioning of the spring phytoplankton bloom in the Bay of Biscay. Limnol. Oceanogr. doi:10.1002/Ino.10769, which has been published in final form at Limnology \& Oceanography. This article may be used for non-commercial purposes in accordance with the Wiley Self-Archiving Policy. 
as bloom timing and duration. In addition, phytoplankton blooms are usually analyzed either in terms of changes in surface or in depth-integrated chlorophyll, ignoring potential changes in vertical structure (Chiswell et al. 2015). Indeed, phytoplankton community structure varies consistently across vertical gradients in the water column, with marked changes in physiological, ecological and taxonomic patterns (Reynolds 2006).

A proper characterization of spring phytoplankton blooms demands high frequency sampling to capture rapid changes in phytoplankton biomass (Rantajärvi et al. 1998). This imposes a major constraint on analyses of change in phytoplankton phenology. The availability of daily satellite ocean color measurements only partially alleviates this problem, given the lack of data during cloudy periods and the limitation of measurements to surface waters (McClain 2009). On the other hand, traditional approaches based on in situ sampling allow the collection of information at different depths, but sustained sampling based on recurrent oceanographic cruises spanning many years is limited to lower frequency sampling (Karl 2010; Church et al. 2013).

We combined monthly in situ data (1993-2012) with quasi-daily satellite observations (1997-2012) to analyze the influence of deep winter mixing on the spring phytoplankton bloom in the central Cantabrian Sea (southern Bay of Biscay). In this temperate sea, nutrient supply to upper layers is largely driven by deep mixing processes during winter (Llope et al. 2007; Hartman et al. 2013), leading to a well-developed spring bloom that is a major feature of the seasonal cycle of phytoplankton (Varela 1996). First, we examined the relationship of winter mixing with nitrate and phytoplankton concentrations through the water column during the spring bloom, considering also short-term variability in the stability of the upper layer. Next, we assessed how inter-annual changes in winter mixing

106 modulate the timing, duration and intensity of the surface expression of the spring bloom. and Anadón, R. (2017), Winter-mixing preconditioning of the spring phytoplankton bloom in the Bay of Biscay. Limnol. Oceanogr. doi:10.1002/Ino.10769, which has been published in final form at Limnology \& Oceanography. This article may be used for non-commercial purposes in accordance with the Wiley Self-Archiving Policy. 
107 Finally, we explored how changes in surface temperature impacts the development of the

108 spring phytoplankton bloom through its influence on winter mixing. Through these

109 analyses, we assess the relative importance of winter mixing on the interannual variability

110 of the spring phytoplankton bloom in temperate seas.

111

This is the accepted version of the following article: González-Gil, R., González Taboada, F., Cáceres, C., Largier, J. L. and Anadón, R. (2017), Winter-mixing preconditioning of the spring phytoplankton bloom in the Bay of Biscay. Limnol. Oceanogr. doi:10.1002/Ino.10769, which has been published in final form at Limnology \& Oceanography. This article may be used for non-commercial purposes in accordance with the Wiley Self-Archiving Policy. 
113 The central Cantabrian Sea (southern Bay of Biscay, Fig. 1) has been sampled

114 intensively for the last two decades as part of the Spanish long-term monitoring network

115 RADIALES (www.seriestemporales-ieo.com, Valdés et al. 2002; Valdés et al. 2007).

116 Here, we used samples collected monthly between 1993 and 2012 at station E3, the most

117 oceanic station of the Cudillero transect. Station E3 is located close to the shelf break,

118 over the Avilés Canyon $\left(06^{\circ} 10^{\prime} \mathrm{W}, 43^{\circ} 46^{\prime} \mathrm{N}\right.$, depth $\left.870 \mathrm{~m}\right)$, and it reflects oceanic

119 conditions typical of a temperate sea. A detailed description of the station and information

120 about the protocols used can be found in Llope et al. (2006). We combined these in situ

121 samples with daily satellite data for surface chlorophyll $a$ concentration ([Chl $\left.a]_{\mathrm{SAT}}\right)$ and

122 sea surface temperature (SST) averaged over a $0.25^{\circ}$ quadrangular pixel centered at

$123 \quad 6.125^{\circ} \mathrm{W}$ and $43.875^{\circ} \mathrm{N}$ (Fig. 1).

In situ oceanographic observations

We used 500-m CTD profiles (SeaBird-25) to assess the intensity of winter mixing between 1993 and 2012. We estimated mixed layer depth (hereafter MLD 0.5 ) as the depth

where the temperature decreases $0.5^{\circ} \mathrm{C}$ with respect to the temperature at $10 \mathrm{~m}$ depth

128 (Monterey and Levitus 1997). Then, we determined annual maximum winter mixing 129 depths $\left(\mathrm{WMD}_{\max }\right)$ from $\mathrm{MLD}_{0.5}$ estimates in winter months (January, February or March),

130 before the spring [Chl $a]_{\text {SAT }}$ maximum (see Statistical analysis and spring bloom metrics 131 section). Incomplete profiles or those showing a thermal inversion were rejected to avoid 132 under- or over-estimating $\mathrm{MLD}_{0.5}$, respectively. Thermal inversions were identified in 133 profiles where temperatures exceeded the 10 -m-depth temperature by $0.1^{\circ} \mathrm{C}$ or more over 134 at least $25 \mathrm{~m}$. It is important to note that, due to the monthly sampling frequency, the deep

This is the accepted version of the following article: González-Gil, R., González Taboada, F., Cáceres, C., Largier, J. L. and Anadón, R. (2017), Winter-mixing preconditioning of the spring phytoplankton bloom in the Bay of Biscay. Limnol. Oceanogr. doi:10.1002/Ino.10769, which has been published in final form at Limnology \& Oceanography. This article may be used for non-commercial purposes in accordance with the Wiley Self-Archiving Policy. 
135 mixing process leading to the measured $\mathrm{WMD}_{\max }$ could have occurred days or weeks

136 before the monthly sampling date, or that later events could lead to deeper mixing before

137 sampling the next profile.

138 Short-term changes in near-surface stratification can mask the influence of winter

139 mixing on spring bloom characteristics. To control for this masking effect, we included

140 the estimated depth of near-surface stratification in our analysis. We estimated the depth

141 of the near-surface stratification (hereafter $\mathrm{MLD}_{0.1}$ ) on each sampling date from the depth

142 at which temperature is $0.1^{\circ} \mathrm{C}$ lower than at $4 \mathrm{~m}$ depth (or at $6 \mathrm{~m}$ depth, if $4 \mathrm{~m}$ was missing;

143 see Dever et al. 2006; Chiswell 2011; Houpert et al. 2015). Daily variations in the near-

144 surface stratification depth affect phytoplankton vertical distribution and the local

145 conditions experienced by phytoplankton cells during the spring bloom (Chiswell 2011;

146 Chiswell et al. 2015; Franks 2015). Heating of surface water is the primary source of

147 stratification, which suppresses near-surface turbulence (Franks 2015). Therefore, the

148 depth of thermal stratification largely controls how far phytoplankton cells can be moved

149 away from the surface and thus determines the amount of light received by phytoplankton.

150 We examined changes in observed nitrate and chlorophyll $a(\mathrm{Chl} a)$ concentrations in

151 the upper $200 \mathrm{~m}$ to analyze the potential bottom-up effects of winter mixing on spring

152 phytoplankton blooms. Nitrate is the most limiting nutrient of phytoplankton growth in

153 the area (Llope et al. 2007), while Chl $a$ data were used as a proxy for phytoplankton

154 biomass. Both nitrate and $\mathrm{Chl} a$ samples were collected at eight depths $(\sim 0,10,20,30$,

$15540,50,75,100,150,200 \mathrm{~m})$ at station E3 using 5-L Niskin bottles. Nitrate samples were

156 frozen and stored at $-20^{\circ} \mathrm{C}$ before measuring nitrate concentrations using a Technicon

157 AAII Autoanalyser (Industrial Method 158-71 W/A) and a Skalar SANplus (Skalar

158 Analytical B.V.). Post-cruise nitrate concentrations were converted from $\mu \mathrm{mol} \mathrm{L}^{-1}$ to

This is the accepted version of the following article: González-Gil, R., González Taboada, F., Cáceres, C., Largier, J. L. and Anadón, R. (2017), Winter-mixing preconditioning of the spring phytoplankton bloom in the Bay of Biscay. Limnol. Oceanogr. doi:10.1002/Ino.10769, which has been published in final form at Limnology \& Oceanography. This article may be used for non-commercial purposes in accordance with the Wiley Self-Archiving Policy. 
$\mu \mathrm{mol} \mathrm{kg}-1$ using water density estimates at average laboratory conditions $\left(22.5^{\circ} \mathrm{C}\right.$ and

$16098.6 \mathrm{kPa}$ at 232 m.a.s.l.). Chl $a$ concentrations were estimated by filtering samples

161 through GF-F filters (25 mm diameter), using $200 \mathrm{~mL}$ for low-Chl $a$ samples, and 100

$162 \mathrm{~mL}$ for high-Chl $a$ samples. These filters were subsequently frozen at $-20^{\circ} \mathrm{C}$. Then, $\mathrm{Chl} a$

163 was extracted in $10 \mathrm{~mL}$ of $90 \%$ acetone over $24 \mathrm{~h}$ in darkness at $4^{\circ} \mathrm{C}$. Chl $a$ concentrations

164 were measured using a Turner Designs 10 fluorometer following the method of Yentsch

165 and Menzel (1963).

166 We explored seasonal and interannual variability in Chl $a$ and nitrate concentrations

167 through the water column using contour plots based on kriging interpolation (Nychka et

168 al. 2015). Before kriging, we used linear interpolation to ensure that the shape of vertical

169 profiles was locally preserved in the contour plots (i.e. by estimating concentrations every

170 two meters). We also used linear interpolation to estimate missing $\mathrm{Chl} a$ and nitrate

171 concentrations in the profile of a given date before calculating depth-integrated values.

172 Linear interpolation was preceded by a $\log _{10}$ transformation of Chl $a$ concentrations. To

173 avoid unreliable estimates, we discarded profiles containing only one data point. We

174 calculated depth-integrated Chl $a$ and nitrate using the trapezoidal rule. Depth-integrated

175 Chl $a$ was calculated for $\sim 0$ to $200 \mathrm{~m}$ depth and regarded as a proxy of total phytoplankton

176 biomass in the water column. Nitrate was integrated from $\sim 0$ to $50 \mathrm{~m}$ depth, just below

177 the nitracline depth during the seasonal stratification (see Figs. 2 and 3). Nitrate in this

178 upper layer is extensively exploited by phytoplankton during the spring bloom. The

179 nitracline was defined by a threshold concentration of $1 \mu \mathrm{mol} \mathrm{kg}{ }^{-1}$, following Cullen and

180 Eppley (1981).

This is the accepted version of the following article: González-Gil, R., González Taboada, F., Cáceres, C., Largier, J. L. and Anadón, R. (2017), Winter-mixing preconditioning of the spring phytoplankton bloom in the Bay of Biscay. Limnol. Oceanogr. doi:10.1002/Ino.10769, which has been published in final form at Limnology \& Oceanography. This article may be used for non-commercial purposes in accordance with the Wiley Self-Archiving Policy. 
182 We used a time series of remotely sensed surface Chl $a$ concentration ([Chl $\left.a]_{\mathrm{SAT}}\right)$ to

183 characterize the development of the spring phytoplankton bloom. In temperate latitudes,

$184[\mathrm{Chl} a]_{\text {SAT }}$ provides a reliable proxy of phytoplankton biomass (McClain 2009). Satellite

185 retrievals were averaged over a $0.25 \times 0.25^{\circ}$ quadrangle covering station E3 (Fig. 1). Daily

186 time series of $[\mathrm{Chl} a]_{\text {SAT }}$ between September 1997 and December 2012 were retrieved

187 from Level 3 (geolocated, corrected and averaged over a regular grid) SeaWiFS (Sept.

188 1997-Dec. 2007, reprocessing R2010.0) and Aqua MODIS (Jul. 2002-Dec. 2012,

189 reprocessing R2013.1.1) standard mapped images (SMI) available at the Ocean Color

190 Web (NASA OBPG 2015a; b). Estimates of [Chl $a]_{\text {SAT }}$ were derived using version six of

191 the OC4 (SeaWiFS) and OC3M (Aqua MODIS) empirical band-ratio algorithms

192 (O'Reilly et al. 2000, oceancolor.gsfc.nasa.gov/cms/atbd/chlor_a).

193 We also used remotely sensed sea surface temperature (SST, see Statistical analysis

194 and spring bloom metrics section). The SST time series (from September 1981 to

195 December 2012) was derived from the NOAA-Optimum Interpolation 1/4 Degree Daily

196 Sea Surface Temperature Analysis (OISST version 2). The methods are described in

197 Reynolds et al. (2007). The database of SST images is produced and maintained by C.

198 Liu and R. W. Reynolds at NCDC (www.ncdc.noaa.gov/oisst). SST is one of the most

199 important parameters in the dynamics of pelagic ecosystems: it has a direct effect on

200 metabolic rates (Eppley 1972; Ikeda 1985), and it is an indicator of many physical

201 processes that affect pelagic organisms, such as mixing and upwelling. Thus, we also

202 explored the relationship between SST and the intensity of mixing in winter.

This is the accepted version of the following article: González-Gil, R., González Taboada, F., Cáceres, C., Largier, J. L. and Anadón, R. (2017), Winter-mixing preconditioning of the spring phytoplankton bloom in the Bay of Biscay. Limnol. Oceanogr. doi:10.1002/Ino.10769, which has been published in final form at Limnology \& Oceanography. This article may be used for non-commercial purposes in accordance with the Wiley Self-Archiving Policy. 

mixing differed depending on whether in situ data or remotely sensed data were used. In

206 the case of in situ sampling, the availability of data through the entire water column 207 allowed us to study variations in the development of the bloom at different depths, 208 considering also concomitant changes in nitrate concentration. On the other hand, higher 209 frequency satellite data allowed extraction of different bloom metrics, although this 210 approach was restricted to surface waters. To conduct our analyses, we combined simple 211 linear regressions and Generalized Additive Models (GAMs, Hastie and Tibshirani 1990).

212 The main characteristic of GAMs is the inclusion of unspecified smooth functions to 213 capture nonlinear relationships among the response and predictor variables (see 214 Supporting information for further details). We assumed independent and identically 215 distributed normal errors in all cases, which required $\log _{10}$ transformation of Chl $a$ data 216 before the analyses (both in situ and satellite). Model assumptions were checked by 217 examining the distribution of residuals. All the statistical analyses were performed in $\mathrm{R}$ 218 version 3.3.3 (R Core Team 2017) using RStudio interface version 1.0.143 (RStudio 219 Team 2016). GAMs were fitted using the functions gam and $\mathrm{t} 2$ from the package mgcv 220 (v1.8-17, Wood 2006; Wood et al. 2013). We also used the package LatticeKrig v6.2 221 (Nychka et al. 2016) for kriging interpolation. Figures were created using package ggplot2 (v2.2.1, Wickham 2009) and graphically improved in Inkscape

This is the accepted version of the following article: González-Gil, R., González Taboada, F., Cáceres, C., Largier, J. L. and Anadón, R. (2017), Winter-mixing preconditioning of the spring phytoplankton bloom in the Bay of Biscay. Limnol. Oceanogr. doi:10.1002/Ino.10769, which has been published in final form at Limnology \& Oceanography. This article may be used for non-commercial purposes in accordance with the Wiley Self-Archiving Policy. 

and $\left.\mathrm{MLD}_{0.1}\right)$, nitrate and Chl $a$. We fitted the following GAM to each physical variable,

227 depth-integrated nitrate and $\mathrm{Chl} a$, surface nitrate concentration and $[\mathrm{Chl} a]_{\mathrm{SAT}}$ (all of 228 them represented below as $y$ ):

$$
y=a+f(t)+\varepsilon
$$

229 The model includes an intercept $(a)$, a 1D smooth function $(f)$ to represent the seasonal 230 curve as a function of day of the year $(t)$ and an error term represented by $\varepsilon$ (see 231 Supporting information for further specifications).

232 In the case of in situ Chl $a$ and nitrate concentration, we estimated the seasonality 233 through the water column using a GAM that included an interaction term between the day 234 of the year $(t)$ and depth $(z)$ :

$$
y=a+t e(t, z)+\varepsilon
$$

where the interaction term $t e(t, z)$ is a $2 \mathrm{D}$ smooth function (specifically, a tensor 236 product) that captures the seasonal cycle of the vertical profiles of Chl $a$ and nitrate concentration over the day of the year (Wood 2006). 
241 bloom Chl $a$ and nitrate concentrations through the water column, we identified the month

242 with maximum surface $\mathrm{Chl} a$ concentration during the first half of each year. We

243 considered this month as representative of conditions during the spring bloom. We

244 formulated then a set of alternative models to explore the influence of $\mathrm{WMD}_{\max }$ and

$245 \mathrm{MLD}_{0.1}$ on vertical profiles of Chl $a$ and nitrate that month (see Table 1). Alternative

246 models were later compared based on Akaike Information Criterion (AIC, Burnham and

247 Anderson 2002). The basic null model, which only included an intercept, was expanded

248 by adding terms for the influence of depth and for the interaction effect between depth

249 and either $\mathrm{WMD}_{\max }$ or $\mathrm{MLD}_{0.1}$ (note that $\mathrm{WMD}_{\max }$ and $\mathrm{MLD}_{0.1}$ were uncorrelated, $r=$

$2500.11, \mathrm{p}$-value $=0.688$ ). These interaction terms were included to capture a distinct depth-

251 dependent effect of $\mathrm{WMD}_{\max }$ or $\mathrm{MLD}_{0.1}$. We completed the analysis by testing the

252 existence of an interaction effect between $\mathrm{WMD}_{\max }$ and $\mathrm{MLD}_{0.1}$, although we limited this

253 analysis to surface waters (See Table 2 for the list of models tested). This enabled an

254 easier comparison with satellite information. Additionally, we explored this interaction

255 effect for depth-integrated Chl $a$.

256 We concluded the analysis of profile data by examining the impact of winter mixing

257 on new primary production $\left(P P_{n e w}\right)$ during the spring bloom. Assuming that the effect of

258 transport and external sources is negligible, we can ascribe the drawdown of nitrate in the

259 upper layers mainly to phytoplankton uptake. This provides a rough approximation of

$260 P P_{\text {new }}\left(\mathrm{mg} \mathrm{C} \mathrm{m}^{-2} \mathrm{day}^{-1}\right)$ during the bloom:

$$
P P_{\text {new }} \sim r_{C: N} \int_{50}^{0} \frac{1}{\Delta t}\left(\left[\mathrm{NO}_{3}\right]_{z, t_{i}}-\left[\mathrm{NO}_{3}\right]_{z, t_{f}}\right) \mathrm{d} z
$$

This is the accepted version of the following article: González-Gil, R., González Taboada, F., Cáceres, C., Largier, J. L. and Anadón, R. (2017), Winter-mixing preconditioning of the spring phytoplankton bloom in the Bay of Biscay. Limnol. Oceanogr. doi:10.1002/Ino.10769, which has been published in final form at Limnology \& Oceanography. This article may be used for non-commercial purposes in accordance with the Wiley Self-Archiving Policy. 
261 where the decay in nitrate concentration $\left[\mathrm{NO}_{3}\right]$ at depth $z\left(\mathrm{~mol} \mathrm{~m}^{-3}\right)$ between February

$262\left(t_{i}\right)$ and April $\left(t_{f}\right)$ was integrated over the upper $50 \mathrm{~m}$ of the water column (i.e. from just

263 below the nitracline depth during the seasonal stratification, see Figs. 2 and 3). For each

264 season, we subtracted nitrate concentrations in February from those recorded in April to

265 cover the entire bloom development. Differences in $\left[\mathrm{NO}_{3}\right]$ were averaged over time using

266 the difference in days between sampling dates, $\Delta t$. The factor used in the conversion from

267 nitrate to carbon units $\left(r_{C: N}=6.6\right)$ was based on a constant $\mathrm{C}: \mathrm{N}$ ratio averaged from the

268 C:N ratios for the new production estimated by Körtzinger et al. (2001) in bloom and

269 early bloom sampling stations during a meridional transect carried out in the Northeast

270 Atlantic. This $r_{C: N}$ coincides with the ratio described by Redfield (1958) for the

271 particulate organic matter in the ocean. We calculated $P P_{\text {new }}$ for each season and

272 compared it with the intensity of winter mixing using a simple linear regression on

$273 \mathrm{WMD}_{\max }$ measured during the preceding winter. We presumed that a positive relationship

274 between $P P_{\text {new }}$ and $\mathrm{WMD}_{\max }$ would be indicative of the preconditioning effect of winter

275 mixing on the spring bloom development.

The high temporal resolution of $[\mathrm{Chl} a]_{\mathrm{SAT}}$ data allowed us to extend the analysis of interannual variability in the spring bloom. To do that, we fitted a GAM featuring a changing seasonal cycle among years both to $[\mathrm{Chl} a]_{\text {SAT }}$ and SST data $(y)$ :

$$
y=a+f(t \mid y e a r)+\varepsilon
$$

281 The $f(t \mid$ year $)$ term is included to capture changes in the seasonality among years. In the

This is the accepted version of the following article: González-Gil, R., González Taboada, F., Cáceres, C., Largier, J. L. and Anadón, R. (2017), Winter-mixing preconditioning of the spring phytoplankton bloom in the Bay of Biscay. Limnol. Oceanogr. doi:10.1002/Ino.10769, which has been published in final form at Limnology \& Oceanography. This article may be used for non-commercial purposes in accordance with the Wiley Self-Archiving Policy. 
model, the seasonal cycle starts in July $15^{\text {th }}$ (or $14^{\text {th }}$ in a leap year). This choice ensured

283 that the seasonal term included the annual SST maximum and the SST minimum in the next year, both required to derive spring bloom metrics (see below). For $[\mathrm{Chl} a]_{\mathrm{SAT}}$, analyses conducted beforehand indicated that there is no need to account for differences in mean concentration or in the shape of the seasonal cycle between sensors (SeaWiFS

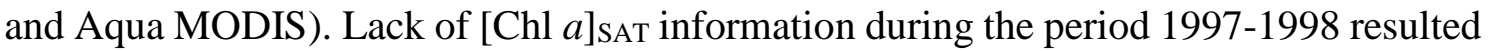
in unreliable estimates of bloom metrics that were not included in the main analyses.

We retrieved a series of metrics to characterize interannual changes in the spring bloom based on modelled time series of $[\mathrm{Chl} a]_{\mathrm{SAT}}(\mathrm{Eq} .4)$. We determined first the timing of the autumn bloom, which follows the annual SST maximum. The autumn bloom was defined as the first local maximum in $[\mathrm{Chl} a]_{\mathrm{SAT}}$ reached after at least 30 consecutive days of increase in $[\mathrm{Chl} a]_{\mathrm{SAT}}$ (this condition prevents confounding this bloom with a small

294 rise in $[\mathrm{Chl} a]_{\mathrm{SAT}}$. Then, we defined spring bloom rise as the day when the seasonal curve 295 of $[\mathrm{Chl} a]_{\text {SAT }}$ increased at the fastest rate following the autumn bloom. If no autumn bloom was observed (i.e. only one $[\mathrm{Chl} a]_{\mathrm{SAT}}$ maximum occurred), then spring bloom rise was

297 defined as the date when the $[\mathrm{Chl} a]_{\text {SAT }}$ seasonal curve increased at the fastest rate. This 298 criterion to identify the timing of the spring bloom avoids the use of an a priori 299 chlorophyll threshold (for references discussing different criteria, see Brody et al. 2013;

300 Blondeau-Patissier et al. 2014; González Taboada and Anadón 2014). We defined bloom 301 decay as the day when the $[\mathrm{Chl} a]_{\mathrm{SAT}}$ seasonal curve decreased at the fastest rate after 302 both the spring bloom maximum (i.e. the magnitude of the spring bloom peak, $\max C h l$ 303 a) and minimum SST. The latter condition allows identification of the real spring bloom 304 decay, avoiding confusion with an early, temporary decrease in [Chl $a]_{\text {SAT }}$ after reaching 305 the $\max C h l a$. The day of occurrence of the $\max C h l a$ was another timing metric (max and Anadón, R. (2017), Winter-mixing preconditioning of the spring phytoplankton bloom in the Bay of Biscay. Limnol. Oceanogr. doi:10.1002/Ino.10769, which has been published in final form at Limnology \& Oceanography. This article may be used for non-commercial purposes in accordance with the Wiley Self-Archiving Policy. 
306 Chl a day). Finally, we identified the bloom span as the number of days between bloom

307 rise and bloom decay.

308 Once we calculated these bloom metrics for each year, we inspected the influence of

309 winter mixing on them by using linear regression analysis. We also used linear

310 regressions to analyze SST long-term trends and to explore the impact of SST on the

311 magnitude of winter mixing at different lags.

This is the accepted version of the following article: González-Gil, R., González Taboada, F., Cáceres, C., Largier, J. L. and Anadón, R. (2017), Winter-mixing preconditioning of the spring phytoplankton bloom in the Bay of Biscay. Limnol. Oceanogr. doi:10.1002/Ino.10769, which has been published in final form at Limnology \& Oceanography. This article may be used for non-commercial purposes in accordance with the Wiley Self-Archiving Policy. 

at different depths, or integrated through the water column, all showed a clear seasonal

317 pattern (Figs. 2 and 3). The seasonal cycle in SST exhibited a maximum of $20.34^{\circ} \mathrm{C}$ in 318 August and a minimum of $12.54^{\circ} \mathrm{C}$ in March (Fig. 3a). In mid-winter (January and 319 February), both $\mathrm{MLD}_{0.5}$ and $\mathrm{MLD}_{0.1}$ were deep, indicating a well-mixed water column 320 (Fig. 3b). Some profiles showed shallower MLD $_{0.1}$ than MLD $_{0.5}$ during the well-mixed period, indicating that transient shallow and weak stratification may develop in winter, accounting for a shallow $\mathrm{MLD}_{0.1}$ being observed above a deeper $\mathrm{MLD}_{0.5}$ that may have formed days or even weeks before the sampling dates. As a consequence of the mixing,

324 nitrate was homogeneously distributed through the water column in mid-winter (average 325 concentration of $4.68 \mu \mathrm{mol} \mathrm{kg}{ }^{-1}$, Fig. 3c), which accounts for the annual maximum in the uppermost $50 \mathrm{~m}$ (Figs. 3c, 3e and 3g). At the end of February, a surface stratified layer started to form (shoaling of $\mathrm{MLD}_{0.1}$ ), which is the beginning of seasonal stratification (Fig. 3b). Concurrently, surface nitrate started to decrease and was very low during the stratification period, from May to October (mean concentration in the top $20 \mathrm{~m}$ of 0.28 $330 \mu \mathrm{mol} \mathrm{kg}{ }^{-1}$ ). This caused the formation of a marked nitracline at $\sim 40 \mathrm{~m}$ depth (Figs. 2a and $3 \mathrm{c})$. except in mid-winter, when mixing homogenized the water column, and in mid-summer

334 when the chlorophyll maximum was observed close to the depth of the nitracline (Fig. 335 3d). Depth-integrated Chl $a$ increased markedly in late December (Fig. 3f), although

This is the accepted version of the following article: González-Gil, R., González Taboada, F., Cáceres, C., Largier, J. L. and Anadón, R. (2017), Winter-mixing preconditioning of the spring phytoplankton bloom in the Bay of Biscay. Limnol. Oceanogr. doi:10.1002/Ino.10769, which has been published in final form at Limnology \& Oceanography. This article may be used for non-commercial purposes in accordance with the Wiley Self-Archiving Policy. 
surface concentrations only increased in late February with the onset of stratification

337 (Figs. 3d and 3h). This fast increase in Chl $a$ corresponds to the spring bloom and accounts

338 for most of the seasonal depletion of near-surface nitrate. It represents the annual

339 maximum in phytoplankton biomass, which generally occurred in March near-surface

340 (Figs. 3d, 3h and 4) and ranged from 0.23 to $5.41 \mathrm{mg} \mathrm{m}^{-3}$ (average $\mathrm{Chl} a$ concentration in

341 the uppermost $20 \mathrm{~m}$ ). The annual maximum decreased in magnitude with depth and

342 occurred later at intermediate-depth waters from 30 to $50 \mathrm{~m}$ (Fig. 4). From June to

343 September, Chl $a$ concentrations remained low near-surface (Figs. 3d and 3h) with the

344 maximum observed between 20 and $50 \mathrm{~m}\left(0.33 \mathrm{mg} \mathrm{m}^{-3}\right.$ on average). Surface $\mathrm{Chl} a$

345 concentration increased again during the autumn bloom, which usually peaked in

346 November (Fig. 3d and 3h) and was weaker than the spring bloom (average Chl $a$

347 concentration of $0.18-2.64 \mathrm{mg} \mathrm{m}^{-3}$ in the uppermost $20 \mathrm{~m}$ ).

Effect of $\mathrm{WMD}_{\max }$ on the vertical structure of the spring bloom

Maximum winter mixing depths $\left(\mathrm{WMD}_{\max }\right)$ exhibited inter-annual variability in both

350 magnitude and timing (Fig. 5a). This variability affected the nutrient supply to surface

351 layers: the deeper the $\mathrm{WMD}_{\max }$, the larger the depth-integrated nitrate over the upper 50

$352 \mathrm{~m}$ (Figs. 5b and 5c). Winter mixing also affected nitrate levels and $\mathrm{Chl} a$ in spring blooms,

353 as seen in Table 1. Data for March were used to analyze this effect, the month in which

354 the near-surface spring bloom typically peaks (Figs. 3d, 3h and 4). The model that

355 includes $\mathrm{WMD}_{\max }$ and $\mathrm{MLD}_{0.1}$ as predictors of nitrate and Chl $a$ concentrations performed

356 best (Table 1). This indicates that both the past and recent history of water-column

357 stratification (i.e. $\mathrm{WMD}_{\max }$ and $\mathrm{MLD}_{0.1}$, respectively) have an effect on nitrate and Chl $a$

358 concentrations during the spring bloom. This model shows that higher nitrate and Chl $a$

359 concentrations in March follow winters with deeper $\mathrm{WMD}_{\max }$ (left panels in Fig. 6). The

This is the accepted version of the following article: González-Gil, R., González Taboada, F., Cáceres, C., Largier, J. L. and Anadón, R. (2017), Winter-mixing preconditioning of the spring phytoplankton bloom in the Bay of Biscay. Limnol. Oceanogr. doi:10.1002/Ino.10769, which has been published in final form at Limnology \& Oceanography. This article may be used for non-commercial purposes in accordance with the Wiley Self-Archiving Policy. 
360 positive effect of $\mathrm{WMD}_{\max }$ on nitrate concentration was more important towards the

361 surface (i.e., the increase in the effect along the $\mathrm{x}$ axis is gradually larger towards

362 shallower depths in the left panel of Fig. 6a). A similar effect was found for Chl $a$; the

363 positive effect of $\mathrm{WMD}_{\max }$ was also strongest in surface waters and it became weaker at

364 deeper depths, especially at intermediate layers (left panel in Fig. 6b). In both cases, the

365 near-surface seasonal depletion of nutrients during stratification (Figs. 3c, 3e and 3g) can

366 explain the higher near-surface sensitivity of nitrate and Chl $a$ to winter mixing.

367 Contrary to the effect of $\mathrm{WMD}_{\max }$, the relationship between near-surface stratification

368 depth $\left(\mathrm{MLD}_{0.1}\right)$ and either nitrate or Chl $a$ concentrations in March varied markedly across

369 depth (right panels in Fig. 6). In the case of nitrate, near-surface concentrations decrease

370 when $\mathrm{MLD}_{0.1}$ is shallow $\left(\mathrm{MLD}_{0.1} \sim 0\right.$ to $75 \mathrm{~m}$, right panel of Fig. 6a), with strongest

371 decreases for shallowest $M L D_{0.1}$. This effect of $\mathrm{MLD}_{0.1}$ on nitrate is consistent with rapid

372 nutrient drawdown when phytoplankton blooms are confined within a thin surface layer

373 (depth given by $\mathrm{MLD}_{0.1}$ ). Consistent with this forcing, large Chl $a$ concentrations are seen

374 near-surface and at depth (below $150 \mathrm{~m}$ ) when $\mathrm{MLD}_{0.1}$ is less than $\sim 100 \mathrm{~m}$ (see right

375 panel of Fig. 6b). The effect in other sections of the water column (below $\sim 50 \mathrm{~m}$ for

376 nitrate, but $\sim 30-150 \mathrm{~m}$ for $\mathrm{Chl} a$ ) peaked at intermediate $\operatorname{MLD}_{0.1}(\sim 50-125 \mathrm{~m})$.

377 Table 2 summarizes the effect of $\mathrm{WMD}_{\max }$ and $\mathrm{MLD}_{0.1}$ on surface nitrate and Chl $a$

378 concentrations in March. In the case of nitrate, the model including only $\mathrm{MLD}_{0.1}$

379 explained around three times more variability than the $\mathrm{WMD}_{\max }$ alone (Table 2); the

380 model including an interaction showed a positive effect of MLD $_{0.1}$, which was similar

381 along the entire $\mathrm{WMD}_{\max }$ range, and a decreasing positive effect of $\mathrm{WMD}_{\max }$ towards

382 deeper $\mathrm{MLD}_{0.1}$ (Fig. 7a). In the case of $\mathrm{Chl} a$, the interaction model outcompeted the

383 others (Table 2). For the analysis of the model outputs portrayed in Fig. 7b, we focused

This is the accepted version of the following article: González-Gil, R., González Taboada, F., Cáceres, C., Largier, J. L. and Anadón, R. (2017), Winter-mixing preconditioning of the spring phytoplankton bloom in the Bay of Biscay. Limnol. Oceanogr. doi:10.1002/Ino.10769, which has been published in final form at Limnology \& Oceanography. This article may be used for non-commercial purposes in accordance with the Wiley Self-Archiving Policy. 
384 on those regions of the sample space with observations. Surface Chl $a$ concentration was

385 maximum for deep $\mathrm{WMD}_{\max }$ and shallow $\mathrm{MLD}_{0.1}$ and showed a secondary maximum for

386 MLD $_{0.1} \sim 50-100 \mathrm{~m}$. Depth-integrated Chl $a$ in March, which was highly correlated with

387 Chl $a$ at 20-30 m depth (Supporting information Fig. S1a), showed a similar response

388 pattern as surface $\mathrm{Chl} a$. However, maximum depth-integrated Chl a showed

389 approximately the same values for $\mathrm{MLD}_{0.1} \sim 50-150 \mathrm{~m}$ as for deep $\mathrm{WMD}_{\max }$ and shallow

$390 \quad$ MLD $_{0.1}$ (Fig. S1b).

391 The new primary production $\left(P P_{\text {new }}\right)$ during the spring bloom, estimated from depth-

392 integrated nitrate $(0-50 \mathrm{~m})$ depletion, was between 30 and $490 \mathrm{mg} \mathrm{C} \mathrm{m}^{-2}$ day $^{-1}$ (Fig. 8).

393 We found a clear relationship between primary production and $\mathrm{WMD}_{\max }\left(\mathrm{R}^{2}=0.41, \mathrm{p}\right.$ -

394 value $=0.026$ ). This model predicts an increase in $P P_{\text {new }}$ of $\sim 64 \mathrm{mg} \mathrm{C} \mathrm{m}^{-2}$ day $^{-1}$ for every

$395100 \mathrm{~m}$ increase in $\mathrm{WMD}_{\max }$.

This is the accepted version of the following article: González-Gil, R., González Taboada, F., Cáceres, C., Largier, J. L. and Anadón, R. (2017), Winter-mixing preconditioning of the spring phytoplankton bloom in the Bay of Biscay. Limnol. Oceanogr. doi:10.1002/Ino.10769, which has been published in final form at Limnology \& Oceanography. This article may be used for non-commercial purposes in accordance with the Wiley Self-Archiving Policy. 

spring phytoplankton bloom at the surface. Spring bloom phenology exhibited high

399 interannual variability (Fig. 9), typically lasting 90 days and peaking between February $40017^{\text {th }}$ and May $22^{\text {nd }}$ (with mean date of April $4^{\text {th }}$ ). The magnitude of the bloom also varied 401 between years, with [Chl $a]_{\text {SAT }}$ peak concentrations ranging from 0.53 to $1.43 \mathrm{mg} \mathrm{m}^{-3}$.

402 Changes in bloom magnitude were positively associated with $\mathrm{WMD}_{\max }$ (Fig. 10e), 403 consistent with the analysis of in situ data. Later blooms with a shorter span followed 404 winters with deeper mixing layers (Figs. 10a and 10i), although the effect of $\mathrm{WMD}_{\max }$ on 405 these timing metrics remained more elusive $\left(\mathrm{R}^{2}=0.15, \mathrm{p}\right.$-value $=0.165$ for bloom rise; $406 \mathrm{R}^{2}=0.18, \mathrm{p}$-value $=0.133$ for bloom span). As mentioned above, the bloom was more 407 productive in years with deep $\mathrm{WMD}_{\max }$ (Fig. 8). Additionally, the later the $\mathrm{WMD}_{\max }$ 408 occurred, the later the spring bloom peaked (Fig. 10h). A simple linear correlation 409 analysis showed that $\mathrm{WMD}_{\max }$ and the $\mathrm{WMD}_{\max }$ sampling day were uncorrelated $(r=$ $410 \quad 0.30, \mathrm{p}$-value $=0.302)$.

412 The $\mathrm{WMD}_{\max }$ was negatively correlated with the SST, indicating that shallower $413 \mathrm{WMD}_{\max }$ follow warmer SST (Fig. 11a). These negative relationships were stronger for 414 SST within $\sim 60$ days prior to the winter mixing event. Thus the December-March SST 415 is most important in accounting for $\mathrm{WMD}_{\max }$, which mostly occurred in February and 416 March (Fig. 5a). On the other hand, the SST seasonal cycle exhibited large interannual 417 variation (Fig. 9). Beyond the observed linear trend $\left(0.30^{\circ} \mathrm{C}\right.$ decade $\left.^{-1}, 1981-2012\right)$, this 418 variation reflects different rates of warming through the year, with largest values observed

This is the accepted version of the following article: González-Gil, R., González Taboada, F., Cáceres, C., Largier, J. L. and Anadón, R. (2017), Winter-mixing preconditioning of the spring phytoplankton bloom in the Bay of Biscay. Limnol. Oceanogr. doi:10.1002/Ino.10769, which has been published in final form at Limnology \& Oceanography. This article may be used for non-commercial purposes in accordance with the Wiley Self-Archiving Policy. 
419 during the period of seasonal stratification (spring to early autumn), when the trend 420 frequently exceeds $0.30{ }^{\circ} \mathrm{C}$ decade $^{-1}$ (Fig. 11b). This positive trend in SST indicates a 421 long-term decline in $\mathrm{WMD}_{\max }$ and consequently in the magnitude of the spring bloom 422 (see Fig. 10e). However, the short length of the record prevented a direct assessment of 423 these trends and further exploration of this link is required.

This is the accepted version of the following article: González-Gil, R., González Taboada, F., Cáceres, C., Largier, J. L. and Anadón, R. (2017), Winter-mixing preconditioning of the spring phytoplankton bloom in the Bay of Biscay. Limnol. Oceanogr. doi:10.1002/Ino.10769, which has been published in final form at Limnology \& Oceanography. This article may be used for non-commercial purposes in accordance with the Wiley Self-Archiving Policy. 
Our results demonstrate a strong winter-mixing preconditioning of the development and characteristics of the spring phytoplankton bloom, modulated by near-surface stratification. Deeper and later winter mixing leads to more intense and later spring blooms. These more intense blooms are also more productive, as indicated by the faster nitrate decrease in near-surface waters. Additionally, we found that higher winter SST is

430 associated with weaker mixing in winter, and thus also associated with weaker spring 431 phytoplankton blooms.

The dynamics of the spring phytoplankton bloom remain a subject of active debate among marine scientists (see Behrenfeld and Boss 2014; Chiswell et al. 2015 for recent reviews). Some of this controversy arises from the adoption of different methods to characterize phytoplankton blooms ( $\mathrm{Ji}$ et al. 2010), with contrasting findings depending on whether the analyses focused on surface or depth-integrated phytoplankton biomass

437 (Chiswell et al. 2015). Nevertheless, both approaches disregard the depth-dependence of the phytoplankton response, which we describe here and that accounts for observed differences in timing and magnitude of the spring bloom. the Northern and Southern Hemisphere, respectively (Siegel et al. 2002; Henson et al.

442 2009; Chiswell et al. 2013). Analogously, in the Bay of Biscay and presumably also in 443 other temperate regions (see for example Chiswell 2011), the spring bloom exhibits an 444 apparent progression into subsurface layers as spring progresses and the water column 445 stratifies. For upper layers, we understand this in terms of changes in the optimal nutrient 446 and light conditions for phytoplankton growth (Klausmeier and Litchman 2001). In deep 
447 layers, the seasonal timing of maximum Chl $a$ might reflect a larger arrival of

448 phytoplankton cells from near-surface waters and positive phytoplankton growth during

449 winter, potentially due to a dilution effect on grazing (Behrenfeld 2010; Behrenfeld 2014;

450 Behrenfeld and Boss 2014). The observed seasonal increase in depth-integrated

451 phytoplankton biomass during winter supports this last aspect to some extent, but our

452 confidence is constrained by limited data availability during winter.

453 The observed seasonal cycle of Chl $a$ in the Bay of Biscay shows that the development

454 of the spring bloom in surface waters occurs in March. A shift from a deep-mixing regime

455 (primarily buoyancy-driven) to a low-turbulence regime (mainly wind-driven) occurs

456 during this critical period (Huisman et al. 1999; Chiswell et al. 2013; Brody and Lozier

457 2014; 2015; Chiswell et al. 2015). This period coincides also with the onset of the

458 seasonal thermal stratification, triggered by a change to positive air-sea heat fluxes

459 (Chiswell 2011; Taylor and Ferrari 2011; Ferrari et al. 2015). Nitrate concentration at the

460 beginning of the spring bloom is largely controlled by the magnitude of deep mixing

461 events in the prior winter, as already shown by Hartman et al. (2013). However, inter-

462 annual changes in the characteristics of upper water masses and different hydrographic

463 processes (e.g. the Iberian Poleward Current, IPC) can modulate the effect of winter

464 mixing on nutrient preconditioning (Llope et al. 2007).

465 Winter convective mixing increases near-surface nutrient concentration directly 466 through nutrient entrainment from deep waters (Mann and Lazier 2006; Sarmiento and

467 Gruber 2006). Additionally, it reduces the time spent by phytoplankton in the euphotic

468 layer, lowering population growth rates (Sverdrup 1953), and also diluting phytoplankton

469 concentrations (Evans and Parslow 1985; Backhaus et al. 2003; D'Asaro 2008). Both

470 processes reduce nutrient uptake by phytoplankton in the upper ocean. However, this

This is the accepted version of the following article: González-Gil, R., González Taboada, F., Cáceres, C., Largier, J. L. and Anadón, R. (2017), Winter-mixing preconditioning of the spring phytoplankton bloom in the Bay of Biscay. Limnol. Oceanogr. doi:10.1002/Ino.10769, which has been published in final form at Limnology \& Oceanography. This article may be used for non-commercial purposes in accordance with the Wiley Self-Archiving Policy. 
471 dilution through mixing also reduces encounter rates with potential grazers, lowering the

472 grazing pressure on phytoplankton population in winter (Yoshie et al. 2003; Behrenfeld

473 2010; Behrenfeld and Boss 2014). Combining the arguments presented above, deeper

474 winter mixing can lead to a high-nutrient, low-grazing environment that may positively

475 precondition phytoplankton growth during the spring bloom. Indeed, our analysis

476 demonstrates that deeper winter mixing is associated with higher nutrient concentrations

477 and more intense blooms in the southern Bay of Biscay.

The physical structure of the water column during the spring bloom, characterized by near-surface stratification, plays also an important role in shaping the vertical distribution of phytoplankton (Chiswell 2011; Brody and Lozier 2015). The thickness of the stratified layer determines how far phytoplankton can be moved downward, away from maximum light intensities (Franks 2015). Shoaling stratification in March keeps phytoplankton closer to the surface and exposed to higher aggregate light, leading to an increase in their growth rates (Chiswell 2011), and rapid removal of nitrate from these surface waters. We observed that surface phytoplankton biomass was enhanced by shallow-intermediate stratified layers, especially after a favorable preconditioning by mid-large winter mixing events. Higher Chl $a$ concentrations at depth during shallow-intermediate stratification and after mid-large winter mixing may be due to larger fluxes of sinking cells due to enhanced phytoplankton growth in the upper layers (Falkowski et al. 1998; Sanders et al. 2014). In temperate seas such as the Bay of Biscay, diatoms become the dominant 491 phytoplankton group during the spring bloom (Fernández and Bode 1994) and their 492 sinking rates can be greater than $100 \mathrm{~m} \mathrm{~d}^{-1}$, enhanced by particle aggregation (Smayda 493 1970; Lampitt 1985; Smetacek 1985; Burd and Jackson 2009). Thus, increased diatom 494 growth in the surface during the bloom might lead to a rapid export of phytoplankton to

This is the accepted version of the following article: González-Gil, R., González Taboada, F., Cáceres, C., Largier, J. L. and Anadón, R. (2017), Winter-mixing preconditioning of the spring phytoplankton bloom in the Bay of Biscay. Limnol. Oceanogr. doi:10.1002/Ino.10769, which has been published in final form at Limnology \& Oceanography. This article may be used for non-commercial purposes in accordance with the Wiley Self-Archiving Policy. 
waters several hundreds of meters below. In our study area, this hypothesis is supported

496 by the large pulses of biogenic silica collected by deep sediment traps during the spring

497 blooms of 2012 and 2013 (Rumín-Caparrós et al. 2016; traps were moored at 1178 and

4981154 m depth over the Avilés Canyon and westwards over the open slope, respectively).

499 Winter-mixing preconditioning also affected different metrics of the spring bloom in

500 the surface layer. As observed in March for in situ Chl $a$ concentrations, the high nutrient

501 environment caused by deeper winter mixing events was associated with larger spring

502 bloom peaks. This positive effect of deep convective mixing on the spring bloom has

503 been observed in other areas of the North Atlantic (Martinez et al. 2011; Behrenfeld et al.

504 2013). However, our results demonstrate that enhanced nitrate concentrations following

505 strong winter mixing also lead to a more rapid uptake of nutrients in spring. This rapid

506 consumption reflects a larger accumulation of phytoplankton biomass and results in a

507 shorter but more intense bloom. In this way, deeper mixing leads to higher community

508 productivity in the Bay of Biscay (Hartman et al. 2013) and larger peaks in spring

509 zooplankton biomass and abundance (González-Gil et al. 2015). This bottom-up

510 perspective is also compatible with top-down mechanisms raised in the context of the

511 Dilution-Recoupling Hypothesis (Behrenfeld 2010). The release of phytoplankton from

512 grazing pressure in winters with enhanced mixing could entail the development of a larger

513 seeding population and a bloom of a greater magnitude. Interestingly, a lower grazing

514 rate could also reduce in situ nutrient regeneration and foster nutrient consumption by

515 enabling higher accumulations of phytoplankton biomass (Banse 1992), with the overall

516 result of more intense blooms with a shortened span.

517 Strong surface cooling processes due to heat losses are one of the major drivers of deep

518 convective events in winter, as observed in 2005 in the Bay of Biscay (Somavilla et al.

This is the accepted version of the following article: González-Gil, R., González Taboada, F., Cáceres, C., Largier, J. L. and Anadón, R. (2017), Winter-mixing preconditioning of the spring phytoplankton bloom in the Bay of Biscay. Limnol. Oceanogr. doi:10.1002/Ino.10769, which has been published in final form at Limnology \& Oceanography. This article may be used for non-commercial purposes in accordance with the Wiley Self-Archiving Policy. 
520 winter storms may contribute to stirring of the water column during deep mixing (Henson

521 et al. 2006). If any or both of these processes occur at the end of winter, they could delay

522 the beginning of thermal stratification or break it temporarily during its initial phase.

523 Thermal stratification of the water column is required for full development of the near-

524 surface spring bloom (Chiswell 2011; Chiswell et al. 2015). Thus, later deep mixing

525 events associated with lower atmospheric temperatures and gales at the end of winter

526 would delay the spring bloom climax (Townsend et al. 1994; Henson et al. 2006; Álvarez

527 et al. 2009). This could explain our observation that later deep winter mixing events

528 caused later spring bloom peaks.

529 The trend towards surface warming in the southern Bay of Biscay in winter is 530 consistent with both observational and model-based increases in heat content in North

531 Atlantic surface waters (Danabasoglu et al. 2012; Taboada and Anadón 2012). A larger

532 increase in surface heat content relative to deeper layers represents increasing stability

533 and the need for larger energy inputs to mix the water column (Levitus et al. 2012). The

534 presumed decay in winter mixing associated with warming surface waters can be

535 expected to cause a decline in the magnitude of the spring phytoplankton bloom in the

536 Cantabrian Sea. Less intense blooms would decrease the strength of the biological pump

537 (Falkowski et al. 1998; Sanders et al. 2014), and they can also lead to a trophic mismatch

538 and a decrease in the production of upper trophic levels (Durant et al. 2007). Nevertheless,

539 the short length of the series analyzed in this study recommends caution in interpreting

540 trend results (e.g. Henson et al. 2010).

541 The impact of large-scale climate patterns such as the North Atlantic Oscillation

542 (NAO, Hurrell and Deser 2009) deters a simple interpretation of the long-term variability

This is the accepted version of the following article: González-Gil, R., González Taboada, F., Cáceres, C., Largier, J. L. and Anadón, R. (2017), Winter-mixing preconditioning of the spring phytoplankton bloom in the Bay of Biscay. Limnol. Oceanogr. doi:10.1002/Ino.10769, which has been published in final form at Limnology \& Oceanography. This article may be used for non-commercial purposes in accordance with the Wiley Self-Archiving Policy. 
543 in the Bay of Biscay associated with climate change. Indeed, changes in the intensity of

544 winter mixing have been linked to changes in atmospheric circulation and air-sea heat

545 fluxes in the Bay of Biscay associated with alternating phases of the NAO (Somavilla

546 Cabrillo et al. 2011). Positive NAO promotes surface warming and shallower mixing in

547 winter. However, extremely deep winter mixing events were common following a

548 decade-long switch in NAO state starting in the mid-1990s. These strong winter mixing

549 events are also associated with negative anomalies of the East Atlantic (EA) pattern that

550 bring cold, northerly winds into the southern Bay of Biscay (Somavilla et al. 2009).

551 Although continued warming might eventually conceal these effects, the consequences

552 of changes in winter mixing, spring stratification and the interaction with long-term

553 forcing remains elusive. Together, our findings recommend a continued monitoring and

554 further analysis of potential changes in plankton phenology in the Bay of Biscay.

This is the accepted version of the following article: González-Gil, R., González Taboada, F., Cáceres, C., Largier, J. L. and Anadón, R. (2017), Winter-mixing preconditioning of the spring phytoplankton bloom in the Bay of Biscay. Limnol. Oceanogr. doi:10.1002/Ino.10769, which has been published in final form at Limnology \& Oceanography. This article may be used for non-commercial purposes in accordance with the Wiley Self-Archiving Policy. 


\section{Conclusions}

556 Deep winter-mixing preconditioning affects nitrate and Chl $a$ concentrations during

557 the spring phytoplankton bloom in oceanic waters of the southern Bay of Biscay. Deeper

558 winter mixing enhances phytoplankton biomass and nitrate concentrations during spring

559 through the entire water column. On shorter time scales, the physical structure of the

560 water column, characterized by the depth of the surface stratified layer, had an important

561 role in shaping the vertical profiles of nitrate and phytoplankton. Our results show that

562 deeper and later winter mixing events led to later and more intense spring blooms. The

563 faster rate of nitrate uptake during this type of bloom indicates enhanced primary

564 production. Finally, we found that warm surface temperatures, especially in winter, were

565 associated with weaker mixing of the water column and consequently, with a smaller

566 spring bloom peak. Observations and predictions of increasing surface temperature in

567 winter thus suggest a potential weakening of the spring bloom and a reduction of upper

568 trophic productivity and deep carbon export in the Bay of Biscay. This might also be

569 observed in other temperate areas in the future.

This is the accepted version of the following article: González-Gil, R., González Taboada, F., Cáceres, C., Largier, J. L. and Anadón, R. (2017), Winter-mixing preconditioning of the spring phytoplankton bloom in the Bay of Biscay. Limnol. Oceanogr. doi:10.1002/Ino.10769, which has been published in final form at Limnology \& Oceanography. This article may be used for non-commercial purposes in accordance with the Wiley Self-Archiving Policy. 
602

603

604

605

606

607

Acuña, J. L., M. López-Alvarez, E. Nogueira, and F. González-Taboada. 2010. Diatom flotation at the onset of the spring phytoplankton bloom: an in situ experiment. Mar. Ecol. Prog. Ser. 400: 115-125. doi:10.3354/meps08405

Álvarez, E., E. Nogueira, J. L. Acuña, M. López-Álvarez, and J. A. Sostres. 2009. Shortterm dynamics of late-winter phytoplankton blooms in a temperate ecosystem (Central Cantabrian Sea, Southern Bay of Biscay). J. Plankton Res. 31: 601-617. doi:10.1093/plankt/fbp012

Backhaus, J. O., E. N. Hegseth, H. Wehde, X. Irigoien, K. Hatten, and K. Logemann. 2003. Convection and primary production in winter. Mar. Ecol. Prog. Ser. 251: 114. doi:10.3354/meps 251001

Banse, K. 1992. Grazing, temporal changes of phytoplankton concentrations, and the microbial loop in the open sea, p. 409-440. In P. G. Falkowski and A. D. Woodhead [eds.], Primary productivity and biogeochemical cycles in the sea. Plenum Press.

Behrenfeld, M. J. 2010. Abandoning Sverdrup's critical depth hypothesis on phytoplankton blooms. Ecology 91: 977-989. doi:10.1890/09-1207.1

Behrenfeld, M. J. 2014. Climate-mediated dance of the plankton. Nat. Clim. Change 4: 880-887. doi:10.1038/nclimate2349

Behrenfeld, M. J., and E. S. Boss. 2014. Resurrecting the ecological underpinnings of ocean plankton blooms. Annu. Rev. Mar. Sci. 6: 167-194. doi:10.1146/annurevmarine-052913-021325

Behrenfeld, M. J., S. C. Doney, I. Lima, E. S. Boss, and D. A. Siegel. 2013. Annual cycles of ecological disturbance and recovery underlying the subarctic Atlantic spring plankton bloom. Glob. Biogeochem. Cycles 27: 526-540. doi:10.1002/gbc.20050

Blondeau-Patissier, D., J. F. R. Gower, A. G. Dekker, S. R. Phinn, and V. E. Brando. 2014. A review of ocean color remote sensing methods and statistical techniques for the detection, mapping and analysis of phytoplankton blooms in coastal and open oceans. Prog. Oceanogr. 123: 123-144. doi:10.1016/j.pocean.2013.12.008

Brody, S. R., and M. S. Lozier. 2014. Changes in dominant mixing length scales as a driver of subpolar phytoplankton bloom initiation in the North Atlantic. Geophys. Res. Lett. 41: 3197-3203. doi:10.1002/2014GL059707

Brody, S. R., and M. S. Lozier. 2015. Characterizing upper-ocean mixing and its effect on the spring phytoplankton bloom with in situ data. ICES J. Mar. Sci. 72: 19611970. doi:10.1093/icesjms/fsv006

Brody, S. R., M. S. Lozier, and J. P. Dunne. 2013. A comparison of methods to determine phytoplankton bloom initiation. J. Geophys. Res.: Oceans 118: 2345-2357. doi:10.1002/jgrc. 20167

This is the accepted version of the following article: González-Gil, R., González Taboada, F., Cáceres, C., Largier, J. L. and Anadón, R. (2017), Winter-mixing preconditioning of the spring phytoplankton bloom in the Bay of Biscay. Limnol. Oceanogr. doi:10.1002/Ino.10769, which has been published in final form at Limnology \& Oceanography. This article may be used for non-commercial purposes in accordance with the Wiley Self-Archiving Policy. 
Burd, A. B., and G. A. Jackson. 2009. Particle aggregation. Annu. Rev. Mar. Sci. 1: 6590. doi:10.1146/annurev.marine.010908.163904

Burnham, K. P., and D. R. Anderson. 2002. Model selection and multimodel inference: a practical information-theoretic approach. Springer-Verlag.

Cullen, J., and R. Eppley. 1981. Chlorophyll maximum layers of the Southern California Bight and possible mechanisms of their formation and maintenance. Oceanol. Acta 4: 23-32. http://archimer.ifremer.fr/doc/00121/23207/.

Cushing, D. 1990. Plankton production and year-class strength in fish populations: an update of the match/mismatch hypothesis. Adv. Mar. Biol. 26: 249-293. doi:10.1016/S0065-2881(08)60202-3

Chiswell, S. M. 2011. Annual cycles and spring blooms in phytoplankton: don't abandon Sverdrup completely. Mar. Ecol. Prog. Ser. 443: 39-50. doi:10.3354/meps09453

Chiswell, S. M., J. Bradford-Grieve, M. G. Hadfield, and S. C. Kennan. 2013. Climatology of surface chlorophyll a, autumn-winter and spring blooms in the southwest Pacific Ocean. J. Geophys. Res.: Oceans 118: 1003-1018. doi:10.1002/jgrc.20088

Chiswell, S. M., P. H. R. Calil, and P. W. Boyd. 2015. Spring blooms and annual cycles of phytoplankton: a unified perspective. J. Plankton Res. 37: 500-508. doi:10.1093/plankt/fbv021

Church, M. J., M. W. Lomas, and F. Muller-Karger. 2013. Sea change: Charting the course for biogeochemical ocean time-series research in a new millennium. Deep Sea Res. Part II 93: 2-15. doi:10.1016/j.dsr2.2013.01.035

D'Asaro, E. A. 2008. Convection and the seeding of the North Atlantic bloom. J. Mar. Syst. 69: 233-237. doi:10.1016/j.jmarsys.2005.08.005

D'Ortenzio, F. and others. 2014. Observing mixed layer depth, nitrate and chlorophyll concentrations in the northwestern Mediterranean: A combined satellite and NO3 profiling floats experiment. Geophys. Res. Lett. 41: 6443-6451. doi:10.1002/2014GL061020

Danabasoglu, G., S. C. Bates, B. P. Briegleb, S. R. Jayne, M. Jochum, W. G. Large, S. Peacock, and S. G. Yeager. 2012. The CCSM4 ocean component. J. Clim. 25: 1361-1389. doi:10.1175/JCLI-D-11-00091.1

Dever, E. P., C. E. Dorman, and J. L. Largier. 2006. Surface boundary-layer variability off Northern California, USA, during upwelling. Deep Sea Res. Part II 53: 28872905. doi:10.1016/j.dsr2.2006.09.001

Durant, J. M., D. Ø. Hjermann, G. Ottersen, and N. C. Stenseth. 2007. Climate and the match or mismatch between predator requirements and resource availability. Clim. Res. 33: 271-283. doi:10.3354/cr033271

This is the accepted version of the following article: González-Gil, R., González Taboada, F., Cáceres, C., Largier, J. L. and Anadón, R. (2017), Winter-mixing preconditioning of the spring phytoplankton bloom in the Bay of Biscay. Limnol. Oceanogr. doi:10.1002/Ino.10769, which has been published in final form at Limnology \& Oceanography. This article may be used for non-commercial purposes in accordance with the Wiley Self-Archiving Policy. 
666

667

668

669

670

671

672

673

Eppley, R. W. 1972. Temperature and phytoplankton growth in the sea. Fish. Bull. 70: 1063-1085.

Evans, G. T., and J. S. Parslow. 1985. A Model of Annual Plankton Cycles. Biological Oceanography 3: 327-347. doi:10.1080/01965581.1985.10749478

Falkowski, P. G., R. T. Barber, and V. Smetacek. 1998. Biogeochemical controls and feedbacks on ocean primary production. Science 281: 200-206. doi: $10.1126 /$ science. 281.5374 .200

Fernández, E., and A. Bode. 1994. Succession of phytoplankton assemblages in relation to the hydrography in the southern Bay of Biscay: a multivariate approach. Sci. Mar.

58:

191-205. http://www.icm.csic.es/scimar/index.php/secId/196/IdArt/2688/.

Ferrari, R., S. T. Merrifield, and J. R. Taylor. 2015. Shutdown of convection triggers increase of surface chlorophyll. J. Mar. Syst. 147: 116-122. doi:10.1016/j.jmarsys.2014.02.009

Ferreira, A. S. A., H. Hátún, F. Counillon, M. R. Payne, and A. W. Visser. 2015. Synoptic-scale analysis of mechanisms driving surface chlorophyll dynamics in the North Atlantic. Biogeosciences 12: 3641-3653. doi:10.5194/bg-12-3641-2015

Fischer, A., E. Moberg, H. Alexander, E. Brownlee, K. Hunter-Cevera, K. Pitz, S. Rosengard, and H. Sosik. 2014. Sixty years of Sverdrup: a retrospective of progress in the study of phytoplankton blooms. Oceanography 27: 222-235. doi:10.5670/oceanog.2014.26

Follows, M., and S. Dutkiewicz. 2002. Meteorological modulation of the North Atlantic spring bloom. Deep Sea Res. Part II 49: 321-344. doi:10.1016/S09670645(01)00105-9

Franks, P. J. S. 2015. Has Sverdrup's critical depth hypothesis been tested? Mixed layers vs. turbulent layers. ICES J. Mar. Sci. 72: 1897-1907. doi:10.1093/icesjms/fsu175

González-Gil, R., F. G. Taboada, J. Höfer, and R. Anadón. 2015. Winter mixing and coastal upwelling drive long-term changes in zooplankton in the Bay of Biscay (1993-2010). J. Plankton Res. 37: 337-351. doi:10.1093/plankt/fbv001

González Taboada, F., and R. Anadón. 2014. Seasonality of North Atlantic phytoplankton from space: impact of environmental forcing on a changing phenology (19982012). Glob. Change Biol. 20: 698-712. doi:10.1111/gcb.12352

Hartman, S. E., M. C. Hartman, D. J. Hydes, Z.-P. Jiang, D. Smythe-Wright, and C. González-Pola. 2013. Seasonal and inter-annual variability in nutrient supply in relation to mixing in the Bay of Biscay. Deep Sea Res. Part II 57: 1303-1312. doi:10.1016/j.dsr2.2013.09.032

Hastie, T. J., and R. J. Tibshirani. 1990. Generalized additive models. Chapman \& Hall/CRC. and Anadón, R. (2017), Winter-mixing preconditioning of the spring phytoplankton bloom in the Bay of Biscay. Limnol. Oceanogr. doi:10.1002/Ino.10769, which has been published in final form at Limnology \& Oceanography. This article may be used for non-commercial purposes in accordance with the Wiley Self-Archiving Policy. 
Henson, S. A., J. P. Dunne, and J. L. Sarmiento. 2009. Decadal variability in North Atlantic phytoplankton blooms. J. Geophys. Res.: Oceans 114: C04013. doi:10.1029/2008JC005139

Henson, S. A., I. Robinson, J. T. Allen, and J. J. Waniek. 2006. Effect of meteorological conditions on interannual variability in timing and magnitude of the spring bloom in the Irminger Basin, North Atlantic. Deep Sea Res. Part I 53: 1601-1615. doi:10.1016/j.dsr.2006.07.009

Henson, S. A., J. L. Sarmiento, J. P. Dunne, L. Bopp, I. Lima, S. C. Doney, J. John, and C. Beaulieu. 2010. Detection of anthropogenic climate change in satellite records of ocean chlorophyll and productivity. Biogeosciences 7: 621-640. doi:10.5194/bg-7-621-2010

Hjort, J. 1914. Fluctuations in the great fisheries of northern Europe viewed in the light of biological research. Rapp. P.-V. Reún. Cons. Intern. Explor. Mer. 20: 1-228.

Houpert, L., P. Testor, X. D. de Madron, S. Somot, F. D'Ortenzio, C. Estournel, and H. Lavigne. 2015. Seasonal cycle of the mixed layer, the seasonal thermocline and the upper-ocean heat storage rate in the Mediterranean Sea derived from observations. Prog. Oceanogr. 132: 333-352. doi:10.1016/j.pocean.2014.11.004

Huisman, J., P. van Oostveen, and F. J. Weissing. 1999. Critical depth and critical turbulence: two different mechanisms for the development of phytoplankton blooms. Limnol. Oceanogr. 44: 1781-1787. doi:10.4319/lo.1999.44.7.1781

Hurrell, J. W., and C. Deser. 2009. North Atlantic climate variability: The role of the North Atlantic Oscillation. J. Mar. Syst. 78: 28-41. doi:10.1016/j.jmarsys.2008.11.026

Ikeda, T. 1985. Metabolic rates of epipelagic marine zooplankton as a function of body mass and temperature. Mar. Biol. 85: 1-11. doi:10.1007/BF00396409

Ji, R., M. Edwards, D. L. Mackas, J. A. Runge, and A. C. Thomas. 2010. Marine plankton phenology and life history in a changing climate: current research and future directions. J. Plankton Res. 32: 1355-1368. doi:10.1093/plankt/fbq062

Karl, D. M. 2010. Oceanic ecosystem time-series programs: Ten lessons learned. Oceanography 23: 104-125. doi:10.5670/oceanog.2010.27

Klausmeier, C. A., and E. Litchman. 2001. Algal games: The vertical distribution of phytoplankton in poorly mixed water columns. Limnol. Oceanogr. 46: 19982007. doi:10.4319/lo.2001.46.8.1998

Koeller, P. and others. 2009. Basin-scale coherence in phenology of shrimps and phytoplankton in the North Atlantic Ocean. Science 324: 791-793. doi:10.1126/science.1170987

Körtzinger, A., W. Koeve, P. Kähler, and L. Mintrop. 2001. C : N ratios in the mixed layer during the productive season in the northeast Atlantic Ocean. Deep Sea Res. Part I 48: 661-688. doi:https://doi.org/10.1016/S0967-0637(00)00051-0

This is the accepted version of the following article: González-Gil, R., González Taboada, F., Cáceres, C., Largier, J. L. and Anadón, R. (2017), Winter-mixing preconditioning of the spring phytoplankton bloom in the Bay of Biscay. Limnol. Oceanogr. doi:10.1002/Ino.10769, which has been published in final form at Limnology \& Oceanography. This article may be used for non-commercial purposes in accordance with the Wiley Self-Archiving Policy. 
Kristiansen, T., K. F. Drinkwater, R. G. Lough, and S. Sundby. 2011. Recruitment variability in North Atlantic cod and match-mismatch dynamics. PLoS One 6: e17456. doi:10.1371/journal.pone.0017456

Lampitt, R. S. 1985. Evidence for the seasonal deposition of detritus to the deep-sea floor and its subsequent resuspension. Deep-Sea Res. Part A Oceanogr. Res. Pap. 32: 885-897. doi:10.1016/0198-0149(85)90034-2

Levitus, S. and others. 2012. World ocean heat content and thermosteric sea level change (0-2000 m), 1955-2010. Geophys. Res. Lett. 39: L10603. doi:10.1029/2012GL051106

Lindemann, C., and M. A. St. John. 2014. A seasonal diary of phytoplankton in the North Atlantic. Front. Mar. Sci. 1: 1-6. doi:10.3389/fmars.2014.00037

Longhurst, A. R., and W. G. Harrison. 1989. The biological pump: profiles of plankton production and consumption in the upper ocean. Prog. Oceanogr. 22: 47-123. doi:10.1016/0079-6611(89)90010-4

Llope, M., R. Anadón, J. Á. Sostres, and L. Viesca. 2007. Nutrients dynamics in the southern Bay of Biscay (1993-2003): winter supply, stoichiometry, long-term trends, and their effects on the phytoplankton community. J. Geophys. Res.: Oceans 112: C07029. doi:10.1029/2006JC003573

Llope, M., R. Anadón, L. Viesca, M. Quevedo, R. González-Quirós, and N. C. Stenseth. 2006. Hydrography of the southern Bay of Biscay shelf-break region: integrating the multiscale physical variability over the period 1993-2003. J. Geophys. Res.: Oceans 111: C09021. doi:10.1029/2005JC002963

Mann, K. H., and J. R. N. Lazier. 2006. Dynamics of marine ecosystems. BiologicalPhysical Interactions in the Oceans, 3rd ed. Blackwell.

Martinez, E., D. Antoine, F. D'Ortenzio, and C. de Boyer Montégut. 2011. Phytoplankton spring and fall blooms in the North Atlantic in the 1980s and 2000s. J. Geophys. Res.: Oceans 116: C11029. doi:10.1029/2010JC006836

McClain, C. R. 2009. A decade of satellite ocean color observations. Annu. Rev. Mar. Sci. 1: 19-42. doi:10.1146/annurev.marine.010908.163650

Monterey, G. I., and S. Levitus. 1997. Seasonal variability of mixed layer depth for the World Ocean. NOAA Atlas NESDIS 14, US Government Printing Office.

Moore, C. M. and others. 2013. Processes and patterns of oceanic nutrient limitation. Nat. Geosci. 6: 701-710. doi:10.1038/ngeo1765

NASA Goddard Space Flight Center, Ocean Ecology Laboratory, Ocean Biology Processing Group (OBPG). 2015a. Moderate-resolution Imaging Spectroradiometer (MODIS) Aqua Chlorophyll Data; 2013.1.1 Reprocessing. NASA OB.DAAC, Greenbelt, MD, USA. doi:10.5067/AQUA/MODIS/L3M/CHL/2014. Accessed on 2015/01/09. 
NASA Goddard Space Flight Center, Ocean Ecology Laboratory, Ocean Biology Processing Group (OBPG). 2015b. Sea-viewing Wide Field-of-view Sensor (SeaWiFS) Chlorophyll Data; 2010.0 Reprocessing. NASA OB.DAAC, Greenbelt, MD, USA. doi:10.5067/AQUA/MODIS/L3M/CHL/2014. Accessed on 2015/01/09.

Nychka, D., S. Bandyopadhyay, D. Hammerling, F. Lindgren, and S. Sain. 2015. A Multiresolution Gaussian Process Model for the Analysis of Large Spatial Datasets. J. Comput. Graph. Stat.

24: $\quad 579-599$.

770

771

772

773

774

775

776

777

778

779

780

781

782

783

784

785

786

787

788

789

790

791

792

793

794

795

796

O'Reilly, J. E. and others. 2000. Ocean color chlorophyll a algorithms for SeaWiFS, OC2, and OC4: Version 4, p. 9-23. In S. B. Hooker and E. R. Firestone [eds.], SeaWiFS Postlaunched Calibration and Validation Analyses, Part 3. NASA Tech. Memo 2000-206892,Vol. 11. NASA, GoddardSpace Flight Center.

Parsons, T. R., and C. M. Lalli. 1988. Comparative oceanic ecology of the plankton communities of the subarctic Atlantic and Pacific oceans. Oceanogr. Mar. Biol. Annu. Rev. 26: 317-359.

Platt, T., C. Fuentes-Yaco, and K. T. Frank. 2003. Spring algal bloom and larval fish survival. Nature 423: 398-399. doi:10.1038/423398b

R Core Team. 2017. R: A language and environment for statistical computing. R Foundation for Statistical Computing, Vienna, Austria. Available from http://www.R-project.org/.

Racault, M.-F., C. Le Quéré, E. Buitenhuis, S. Sathyendranath, and T. Platt. 2012. Phytoplankton phenology in the global ocean. Ecol. Indicators 14: 152-163. doi:10.1016/j.ecolind.2011.07.010

Rantajärvi, E., R. Olsonen, S. Hällfors, J.-M. Leppänen, and M. Raateoja. 1998. Effect of sampling frequency on detection of natural variability in phytoplankton: unattended high-frequency measurements on board ferries in the Baltic Sea. ICES J. Mar. Sci. 55: 697-704. doi:10.1006/jmsc.1998.0384

Redfield, A. C. 1958. The biological control of chemical factors in the environment. Am. Sci. 46: 230A-221.

Reynolds, C. S. 2006. The ecology of phytoplankton. Cambridge University Press.

This is the accepted version of the following article: González-Gil, R., González Taboada, F., Cáceres, C., Largier, J. L. and Anadón, R. (2017), Winter-mixing preconditioning of the spring phytoplankton bloom in the Bay of Biscay. Limnol. Oceanogr. doi:10.1002/Ino.10769, which has been published in final form at Limnology \& Oceanography. This article may be used for non-commercial purposes in accordance with the Wiley Self-Archiving Policy. 
802

803

804

805

806

807

808

809

810

811

812

813

814

815

816

817

818

819

820

821

822

823

824

825

826

827

828

829

830

831

832

833

Reynolds, R. W., T. M. Smith, C. Liu, D. B. Chelton, K. S. Casey, and M. G. Schlax. 2007. Daily high-resolution-blended analyses for sea surface temperature. J. Clim. 20: 5473-5496. doi:10.1175/2007JCLI1824.1

RStudio Team. 2016. RStudio: Integrated Development Environment for R. RStudio, Inc., Boston, MA. Avialable from http://www.rstudio.com.

Rumín-Caparrós, A., A. Sanchez-Vidal, C. González-Pola, G. Lastras, A. Calafat, and M. Canals. 2016. Particle fluxes and their drivers in the Avilés submarine canyon and adjacent slope, central Cantabrian margin, Bay of Biscay. Prog. Oceanogr. 144: 39-61. doi:https://doi.org/10.1016/j.pocean.2016.03.004

Sambrotto, R. N., H. J. Niebauer, J. J. Goering, and R. L. Iverson. 1986. Relationships among vertical mixing, nitrate uptake, and phytoplankton growth during the spring bloom in the southeast Bering Sea middle shelf. Cont. Shelf Res. 5: 161198. doi:10.1016/0278-4343(86)90014-2

Sanders, R. and others. 2014. The biological carbon pump in the North Atlantic. Prog. Oceanogr. 129: 200-218. doi:10.1016/j.pocean.2014.05.005

Sarmiento, J. L., and N. Gruber. 2006. Ocean biogeochemical dynamics. Princeton University Press.

Siegel, D. A., S. C. Doney, and J. A. Yoder. 2002. The North Atlantic spring phytoplankton bloom and Sverdrup's critical depth hypothesis. Science 296: 730733. doi:10.1126/science. 1069174

Sieracki, M. E., P. G. Verity, and D. K. Stoecker. 1993. Plankton community response to sequential silicate and nitrate depletion during the 1989 North Atlantic spring bloom. Deep Sea Res. Part II 40: 213-225. doi:10.1016/0967-0645(93)90014-E

Smayda, T. J. 1970. The suspension and sinking of phytoplankton in the sea. Oceanogr. Mar. Biol. Annu. Rev. 8: 353-414. doi:10.1002/iroh.19720570110

Smetacek, V. S. 1985. Role of sinking in diatom life-history cycles: ecological, evolutionary and geological significance. Mar. Biol. 84: 239-251. doi:10.1007/BF00392493

Somavilla Cabrillo, R., C. González-Pola, M. Ruiz-Villarreal, and A. Lavín Montero. 2011. Mixed layer depth (MLD) variability in the southern Bay of Biscay. Deepening of winter MLDs concurrent with generalized upper water warming trends? Ocean. Dynam. 61: 1215-1235. doi:10.1007/s10236-011-0407-6

Somavilla, R., C. González-Pola, C. Rodriguez, S. A. Josey, R. F. Sánchez, and A. Lavín. 2009. Large changes in the hydrographic structure of the Bay of Biscay after the extreme mixing of winter 2005. J. Geophys. Res.: Oceans 114: C01001. doi:10.1029/2008JC004974

This is the accepted version of the following article: González-Gil, R., González Taboada, F., Cáceres, C., Largier, J. L. and Anadón, R. (2017), Winter-mixing preconditioning of the spring phytoplankton bloom in the Bay of Biscay. Limnol. Oceanogr. doi:10.1002/Ino.10769, which has been published in final form at Limnology \& Oceanography. This article may be used for non-commercial purposes in accordance with the Wiley Self-Archiving Policy. 
Sverdrup, H. U. 1953. On conditions for the Vernal Blooming of Phytoplankton. J. Cons. Int. Explor. Mer. 18: 287-295. doi:10.1093/icesjms/18.3.287

Taboada, F. G., and R. Anadón. 2012. Patterns of change in sea surface temperature in the North Atlantic during the last three decades: beyond mean trends. Clim. Change 115: 419-431. doi:10.1007/s10584-012-0485-6

Taylor, J. R., and R. Ferrari. 2011. Shutdown of turbulent convection as a new criterion for the onset of spring phytoplankton blooms. Limnol. Oceanogr. 56: 2293-2307. doi:10.4319/lo.2011.56.6.2293

Townsend, D. W., L. M. Cammen, P. M. Holligan, D. E. Campbell, and N. R. Pettigrew. 1994. Causes and consequences of variability in the timing of spring phytoplankton blooms. Deep Sea Res. Part I 41: 747-765. doi:10.1016/09670637(94)90075-2

Ueyama, R., and B. C. Monger. 2005. Wind-induced modulation of seasonal phytoplankton blooms in the North Atlantic derived from satellite observations. Limnol. Oceanogr. 50: 1820-1829. doi:10.4319/lo.2005.50.6.1820

Valdés, L., A. Lavín, M. L. Fernández de Puelles, M. Varela, R. Anadón, A. Miranda, J. Camiñas, and J. Mas. 2002. Spanish Ocean Observation System. IEO Core Project: studies on time series of oceanographic data. Elsevier Oceanogr. Ser. 66: 99-105. doi:10.1016/S0422-9894(02)80014-9

Valdés, L. and others. 2007. A decade of sampling in the Bay of Biscay: What are the zooplankton time series telling us? Prog. Oceanogr. 74: 98-114. doi:10.1016/j.pocean.2007.04.016

Varela, M. 1996. Phytoplankton ecology in the Bay of Biscay. Sci. Mar. 60: 45-53.

Wickham, H. 2009. ggplot2: elegant graphics for data analysis. Springer.

Williams, R. G., and M. J. Follows. 2003. Physical transport of nutrients and the maintenance of biological production, p. 19-51. In M. J. R. Fasham [ed.], Ocean Biogeochemistry: The Role of the Ocean Carbon Cycle in Global Change. Springer.

Wood, S. N. 2006. Generalized additive models: an introduction with R. Chapman and Hall/CRC.

Wood, S. N., F. Scheipl, and J. J. Faraway. 2013. Straightforward intermediate rank tensor product smoothing in mixed models. Stat. Comput. 23: 341-360. doi:10.1007/s11222-012-9314-z

Yentsch, C. S., and D. W. Menzel. 1963. A method for the determination of phytoplankton chlorophyll and phaeophytin by fluorescence. Deep-Sea Res. Oceanogr. Abstr. 10: 221-231. doi:10.1016/0011-7471(63)90358-9 
Yoder, J. A., C. R. McClain, G. C. Feldman, and W. E. Esaias. 1993. Annual cycles of phytoplankton chlorophyll concentrations in the global ocean: A satellite view. Glob. Biogeochem. Cycles 7: 181-193. doi:10.1029/93GB02358

873 Yoshie, N., Y. Yamanaka, M. J. Kishi, and H. Saito. 2003. One dimensional ecosystem model simulation of the effects of vertical dilution by the winter mixing on the spring diatom bloom. J. Oceanogr.

59: 563-571. doi:10.1023/B:JOCE.0000009586.02554.d3 
879 We thank all the people that helped in the establishment and maintenance of the time 880 series collected at station E3 (Cudillero Transect), especially those from the Areas of 881 Ecology and Zoology of the University of Oviedo and the entire crew from the research 882 vessel José Rioja. We also thank NASA Ocean Biology Processing Group (OBPG) and

883 NOAA National Climatic Data Center (NCDC) for the production, availability and 884 maintenance of the remote sensing data analyzed in this work. We are especially grateful 885 to D. Tommasi, A. Rivera and S. Romero for their useful comments. Cudillero time series 886 are part of the project RADIALES, Instituto Español de Oceanografía (IEO). This is a 887 contribution of the Asturias Marine Observatory.

This research was co-funded by the agreement "Control a largo plazo de las 889 condiciones químico-biológicas de la Plataforma Continental de Asturias" [Instituto 890 Español de Oceanografía (IEO) and University of Oviedo] and by the project DOS 891 MARES (CTM2010-21810- C03-02, Ministerio de Economía y Competitividad, 892 Gobierno de España). R.G.-G. was supported by a FPU fellowship from the Ministerio 893 de Educación, Cultura y Deporte, Gobierno de España.

This is the accepted version of the following article: González-Gil, R., González Taboada, F., Cáceres, C., Largier, J. L. and Anadón, R. (2017), Winter-mixing preconditioning of the spring phytoplankton bloom in the Bay of Biscay. Limnol. Oceanogr. doi:10.1002/Ino.10769, which has been published in final form at Limnology \& Oceanography. This article may be used for non-commercial purposes in accordance with the Wiley Self-Archiving Policy. 


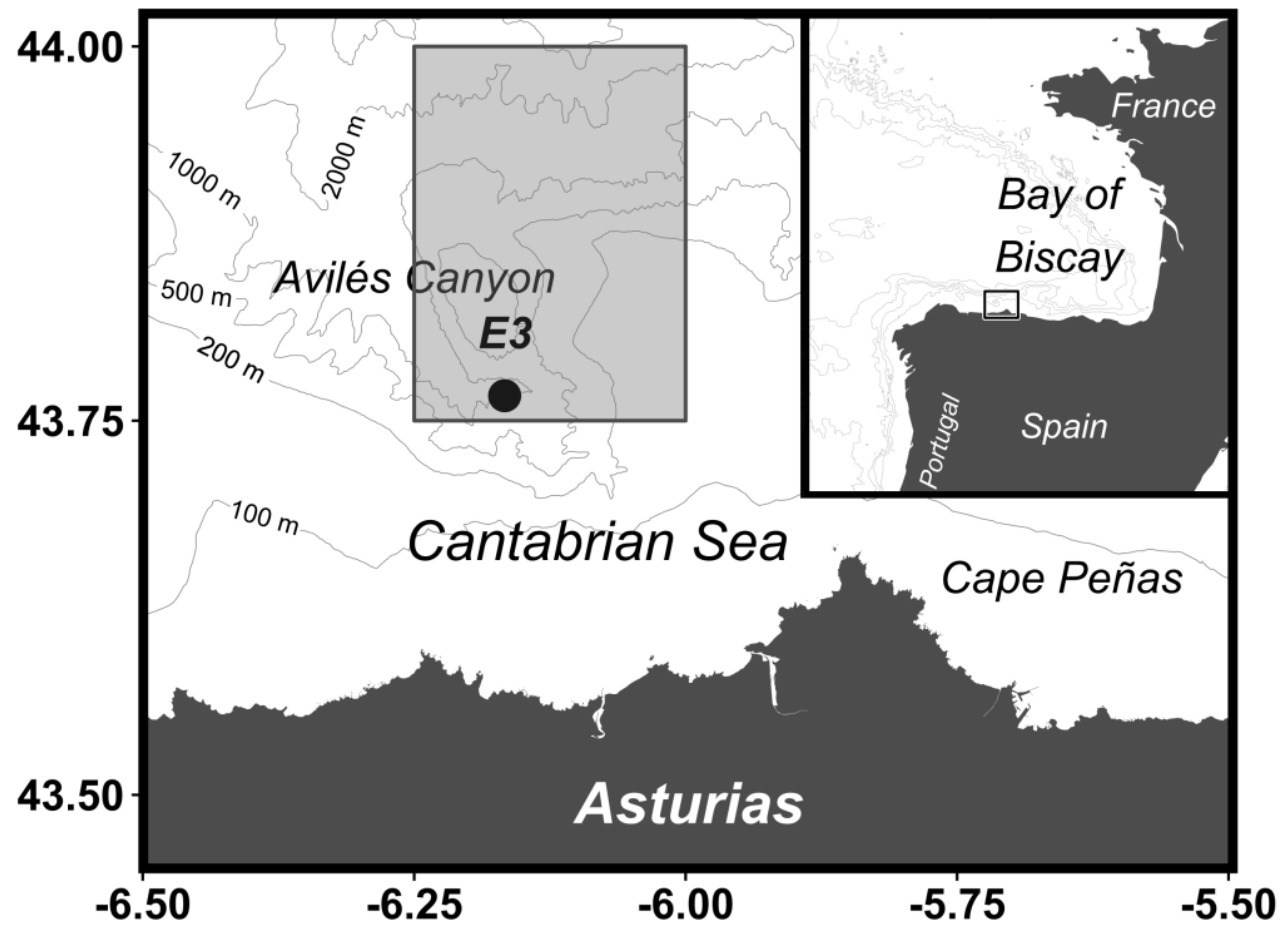

Fig. 1. Map of the study area in the central Cantabrian Sea and its position in the Bay of Biscay. The shaded region around station E3 (dot) corresponds to the $0.25^{\circ} \times 0.25^{\circ}$ quadrangle used to average satellite data.

This is the accepted version of the following article: González-Gil, R., González Taboada, F., Cáceres, C., Largier, J. L. and Anadón, R. (2017), Winter-mixing preconditioning of the spring phytoplankton bloom in the Bay of Biscay. Limnol. Oceanogr. doi:10.1002/Ino.10769, which has been published in final form at Limnology \& Oceanography. This article may be used for non-commercial purposes in accordance with the Wiley Self-Archiving Policy. 
a

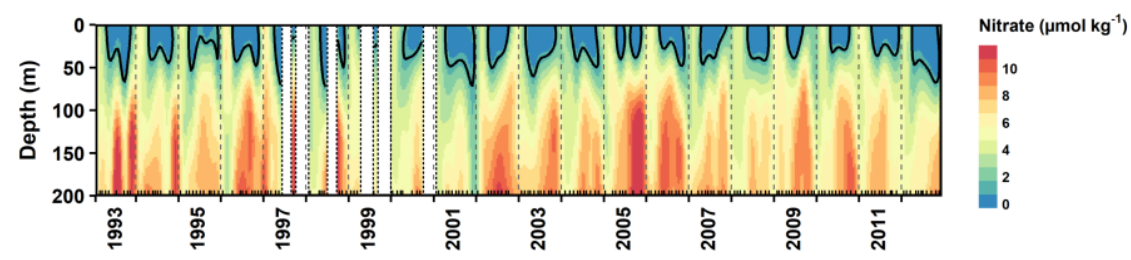

b
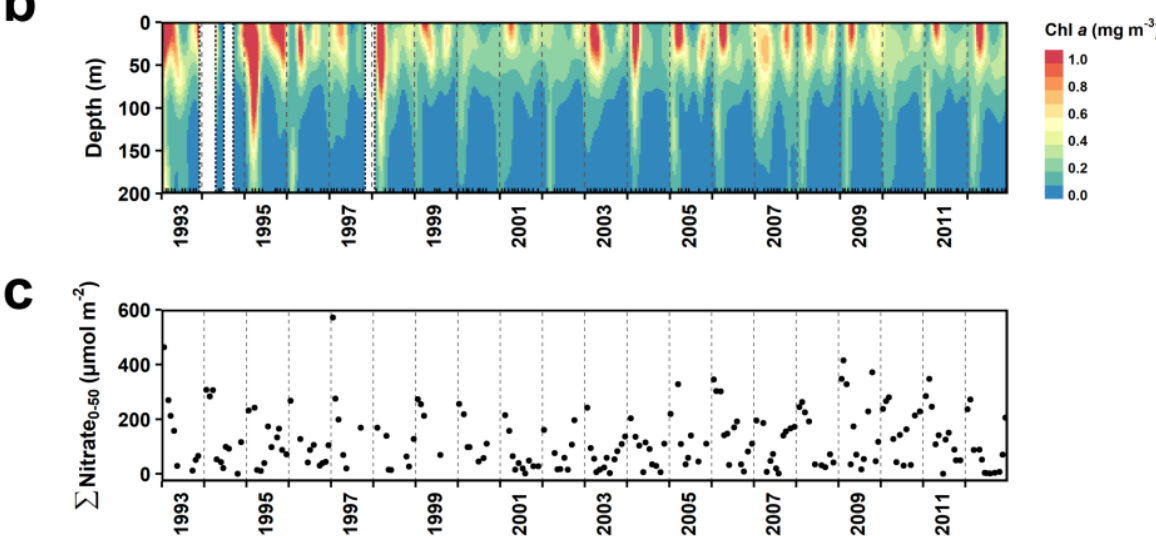

d

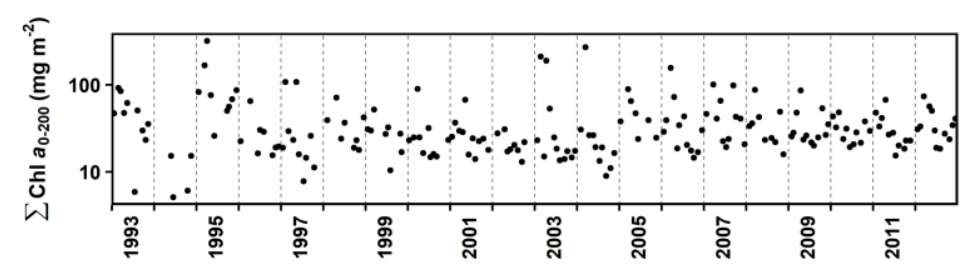

e

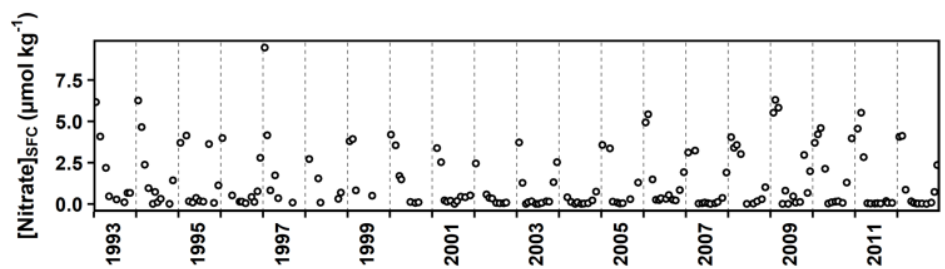

f

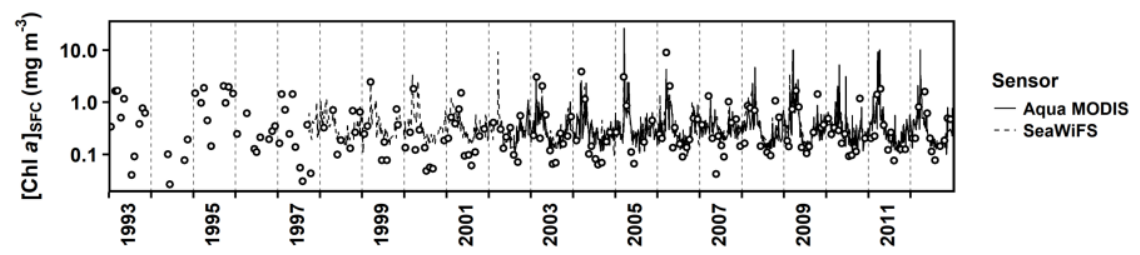

Fig. 2. Intra- and interannual variations in: (a) nitrate and (b) Chl $a$ concentrations over the uppermost $200 \mathrm{~m}$ of the water column interpolated using kriging techniques, (c) depth-integrated nitrate (0-50 m, $\Sigma$ Nitrate0-50), (d) depth-integrated Chl $a\left(0-200 \mathrm{~m}, \Sigma \mathrm{Chl} a_{0}-200\right)$, (e) surface nitrate concentration ([Nitrate $]_{\mathrm{SFC}}$ ) and (f) surface Chl $a$ concentration ([Chl $\left.a\right]_{\mathrm{SFC}}$ ) from in situ (dots) and satellite (lines) observations. In all panels, years are separated by gray vertical dashed lines. In (a) and (b), inner tick marks on the x-axis indicate those dates when data were collected, and data gaps spanning three or more consecutive months appear as blank stripes delimited by vertical dotted lines. The thick contour line in (a) denotes the $1 \mu \mathrm{mol} \mathrm{kg}-1$ nitrate isoline (i.e. the nitracline). Note the use of a log $\log _{10} \mathrm{scale}$ for Chl $a$ in panels (d) and (f).

This is the accepted version of the following article: González-Gil, R., González Taboada, F., Cáceres, C., Largier, J. L. and Anadón, R. (2017), Winter-mixing preconditioning of the spring phytoplankton bloom in the Bay of Biscay. Limnol. Oceanogr. doi:10.1002/Ino.10769, which has been published in final form at Limnology \& Oceanography. This article may be used for non-commercial purposes in accordance with the Wiley Self-Archiving Policy. 
a

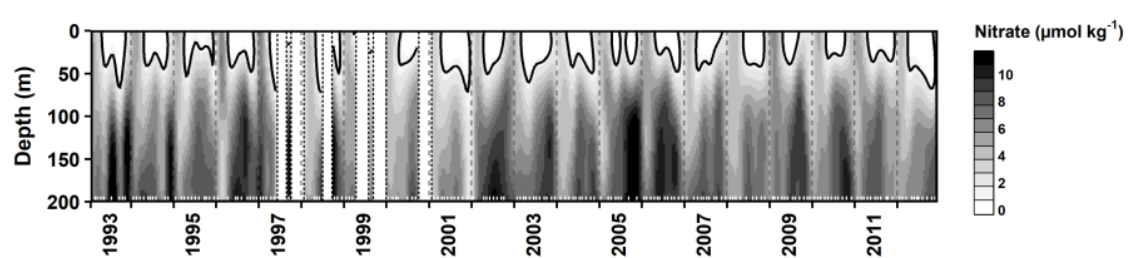

b
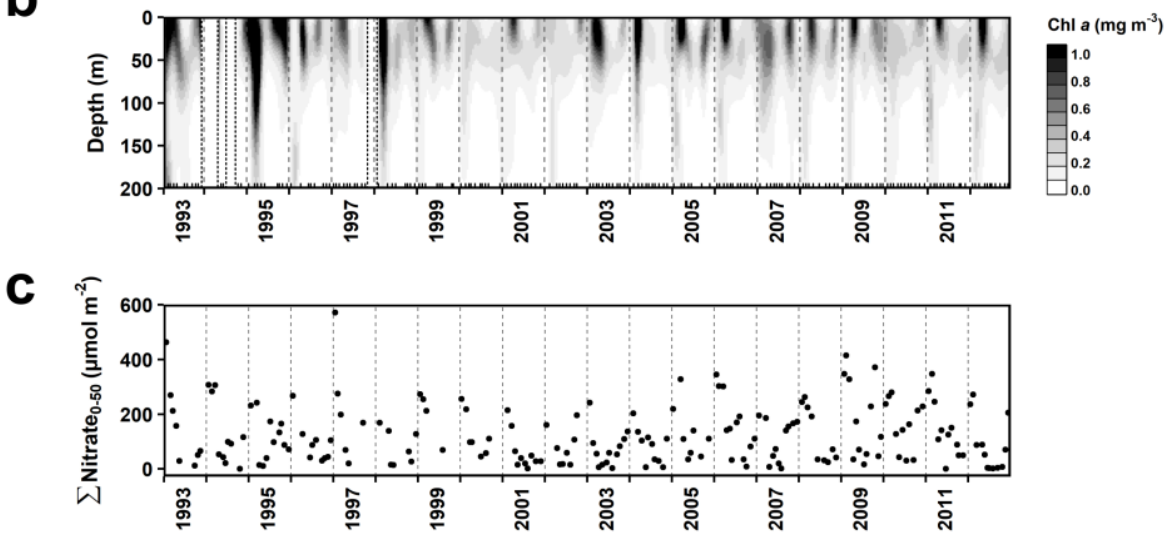

d

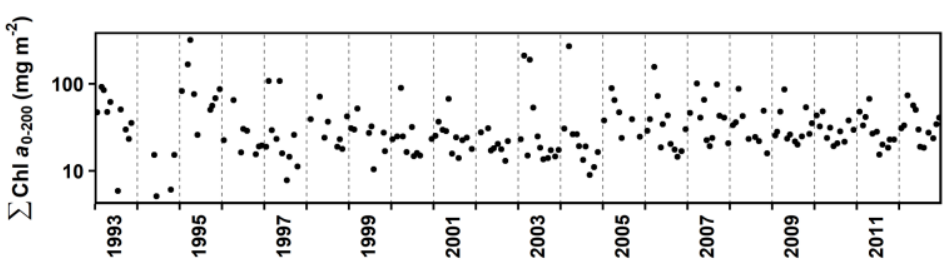

e

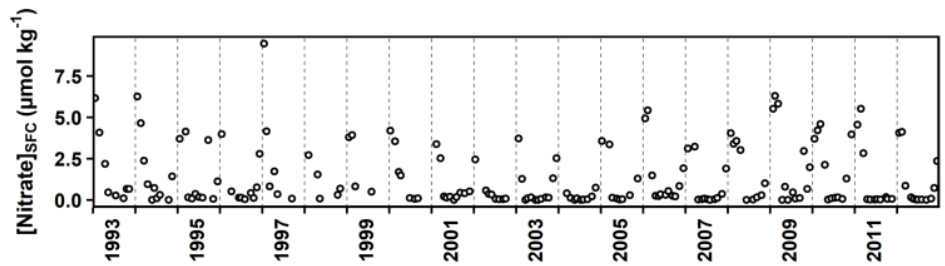

$\mathbf{f}$

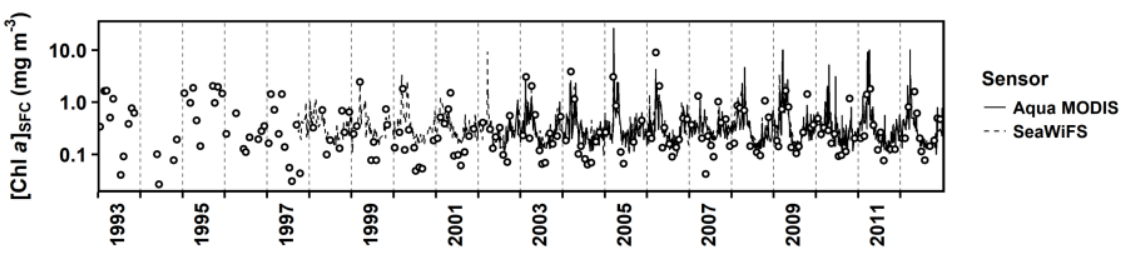

Fig. 2 (b/w). Intra- and interannual variations in: (a) nitrate and (b) Chl $a$ concentrations over the uppermost $200 \mathrm{~m}$ of the water column interpolated using kriging techniques, (c) depth-integrated nitrate (0-50 m, $\Sigma$ Nitrate $\left._{0-50}\right)$, (d) depth-integrated Chl $a\left(0-200 \mathrm{~m}, \Sigma \mathrm{Chl} a_{0-200}\right)$, (e) surface nitrate concentration ([Nitrate $]_{\mathrm{SFC}}$ ) and (f) surface $\mathrm{Chl} a$ concentration ([Chl $\left.a\right]_{\mathrm{SFC}}$ ) from in situ (dots) and satellite (lines) observations. In all panels, years are separated by gray vertical dashed lines. In (a) and (b), inner tick marks on the x-axis indicate those dates when data were collected, and data gaps spanning three or more consecutive months appear as blank stripes delimited by vertical dotted lines. The thick contour line in (a) denotes the $1 \mu \mathrm{mol} \mathrm{kg}-1$ nitrate isoline (i.e. the nitracline). Note the use of a $\log _{10} \mathrm{scale}$ for Chl $a$ in panels (d) and (f).

This is the accepted version of the following article: González-Gil, R., González Taboada, F., Cáceres, C., Largier, J. L. and Anadón, R. (2017), Winter-mixing preconditioning of the spring phytoplankton bloom in the Bay of Biscay. Limnol. Oceanogr. doi:10.1002/Ino.10769, which has been published in final form at Limnology \& Oceanography. This article may be used for non-commercial purposes in accordance with the Wiley Self-Archiving Policy. 

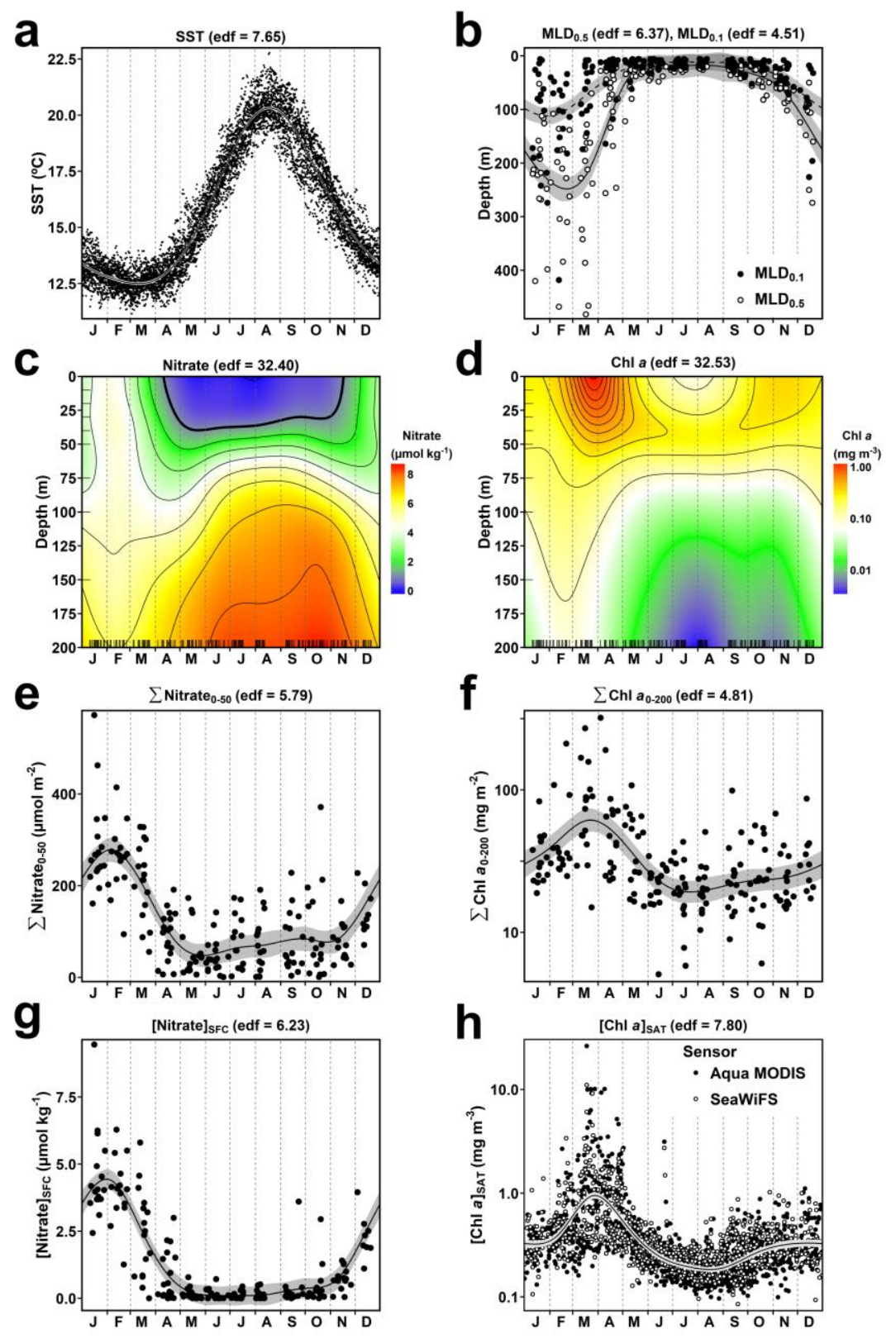

Fig. 3. Seasonality of: (a) sea surface temperature (SST) based on satellite retrievals, (b) mixed layer depth (MLD) calculated using two different criteria (see Material and methods), (c) nitrate and (d) Chl a concentration over the first $200 \mathrm{~m}$ of the water column, (e) depthintegrated nitrate (0-50 m, $\Sigma$ Nitrate $\left._{0-50}\right)$, (f) depth-integrated $\mathrm{Chl} a\left(0-200 \mathrm{~m}, \Sigma \mathrm{Chl} a_{0-200}\right),(\mathrm{g})$ surface nitrate concentration ([Nitrate] $\left.\mathrm{SFC}_{\mathrm{SC}}\right)$ and (h) surface satellite $\mathrm{Chl} a$ concentration ([Chl $a]_{\mathrm{SAT}}$ ). Observed concentrations or integrated values (dots) and estimated seasonal cycles (solid lines in $\mathbf{a}-\mathbf{b}$ and $\mathbf{e}-\mathbf{h}$ or contour plots in $\mathbf{c - d}$ ) are shown. In (a-b) and (e-h), the 95\% confidence intervals (shaded areas) associated with the estimated seasonal cycles are shown. Predicted values for each variable are based on the output of the generalized additive models (GAMs). The estimated degrees of freedom (edf) for each model are indicated. The inner tick marks on each axis in (c) and (d) indicate where data were available. The thick contour line in (c) denotes the $1 \mu \mathrm{mol} \mathrm{kg}^{-1}$ nitrate isoline (i.e. the nitracline). Note the use of a $\log _{10}$ scale for Chl $a$.

This is the accepted version of the following article: González-Gil, R., González Taboada, F., Cáceres, C., Largier, J. L. and Anadón, R. (2017), Winter-mixing preconditioning of the spring phytoplankton bloom in the Bay of Biscay. Limnol. Oceanogr. doi:10.1002/Ino.10769, which has been published in final form at Limnology \& Oceanography. This article may be used for non-commercial purposes in accordance with the Wiley Self-Archiving Policy. 

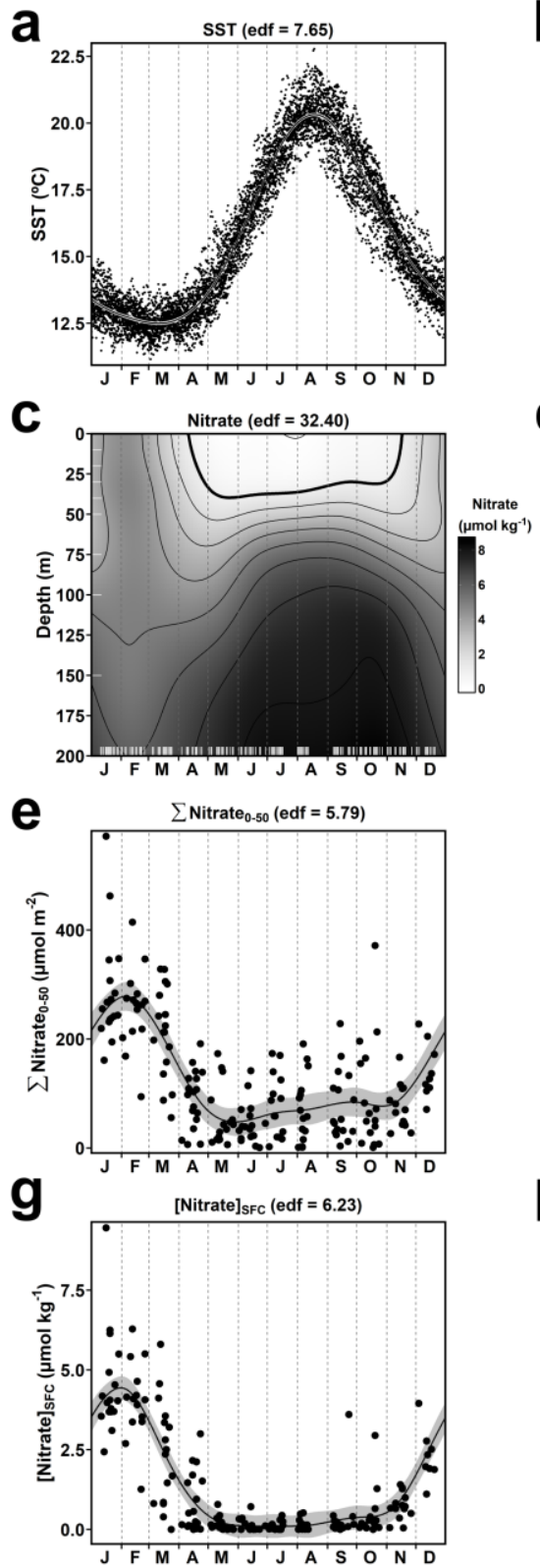

b

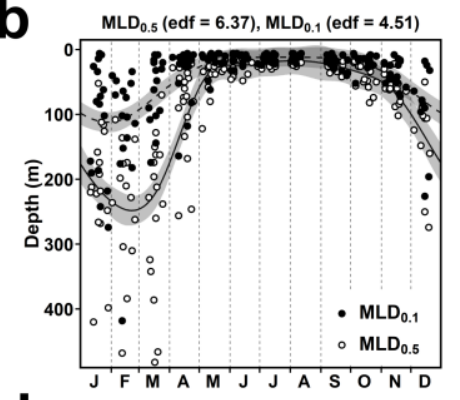

d

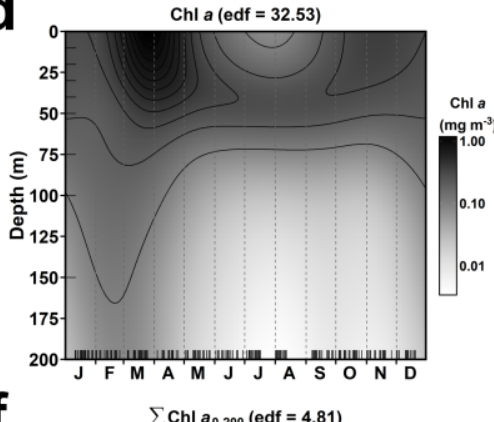

f

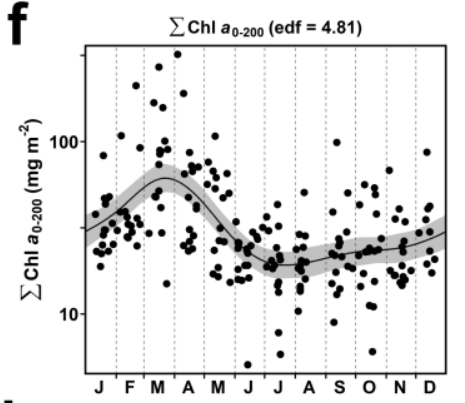

h

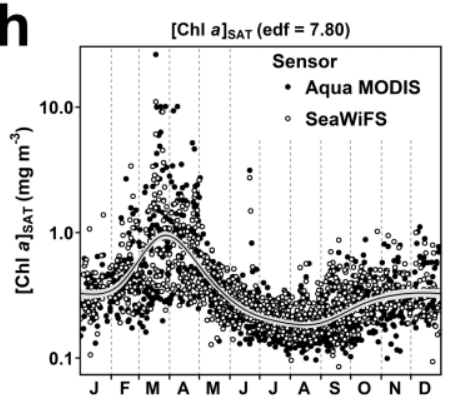

Fig. 3 (b/w). Seasonality of: (a) sea surface temperature (SST) based on satellite retrievals, (b) mixed layer depth (MLD) calculated using two different criteria (see Material and methods), (c) nitrate and (d) Chl $a$ concentration over the first $200 \mathrm{~m}$ of the water column, (e) depthintegrated nitrate $\left(0-50 \mathrm{~m}, \Sigma \mathrm{Nitrate}_{0-50}\right)$, (f) depth-integrated $\mathrm{Chl} a\left(0-200 \mathrm{~m}, \Sigma \mathrm{Chl} a_{0-200}\right),(\mathrm{g})$ surface nitrate concentration ([Nitrate]SFC $)$ and (h) surface satellite $\mathrm{Chl} a$ concentration ([Chl $a]_{\mathrm{SAT}}$ ). Observed concentrations or integrated values (dots) and estimated seasonal cycles (solid lines in $\mathbf{a}-\mathbf{b}$ and $\mathbf{e}-\mathbf{h}$ or contour plots in $\mathbf{c - d})$ are shown. In (a-b) and (e-h), the 95\% confidence intervals (shaded areas) associated with the estimated seasonal cycles are shown. Predicted values for each variable are based on the output of the generalized additive models (GAMs). The estimated degrees of freedom (edf) for each model are indicated. The inner tick marks on each axis in (c) and (d) indicate where data were available. The thick contour line in (c) denotes the $1 \mu \mathrm{mol} \mathrm{kg}^{-1}$ nitrate isoline (i.e. the nitracline). Note the use of a $\log _{10} \mathrm{scale}$ for Chl $a$.

This is the accepted version of the following article: González-Gil, R., González Taboada, F., Cáceres, C., Largier, J. L. and Anadón, R. (2017), Winter-mixing preconditioning of the spring phytoplankton bloom in the Bay of Biscay. Limnol. Oceanogr. doi:10.1002/Ino.10769, which has been published in final form at Limnology \& Oceanography. This article may be used for non-commercial purposes in accordance with the Wiley Self-Archiving Policy. 


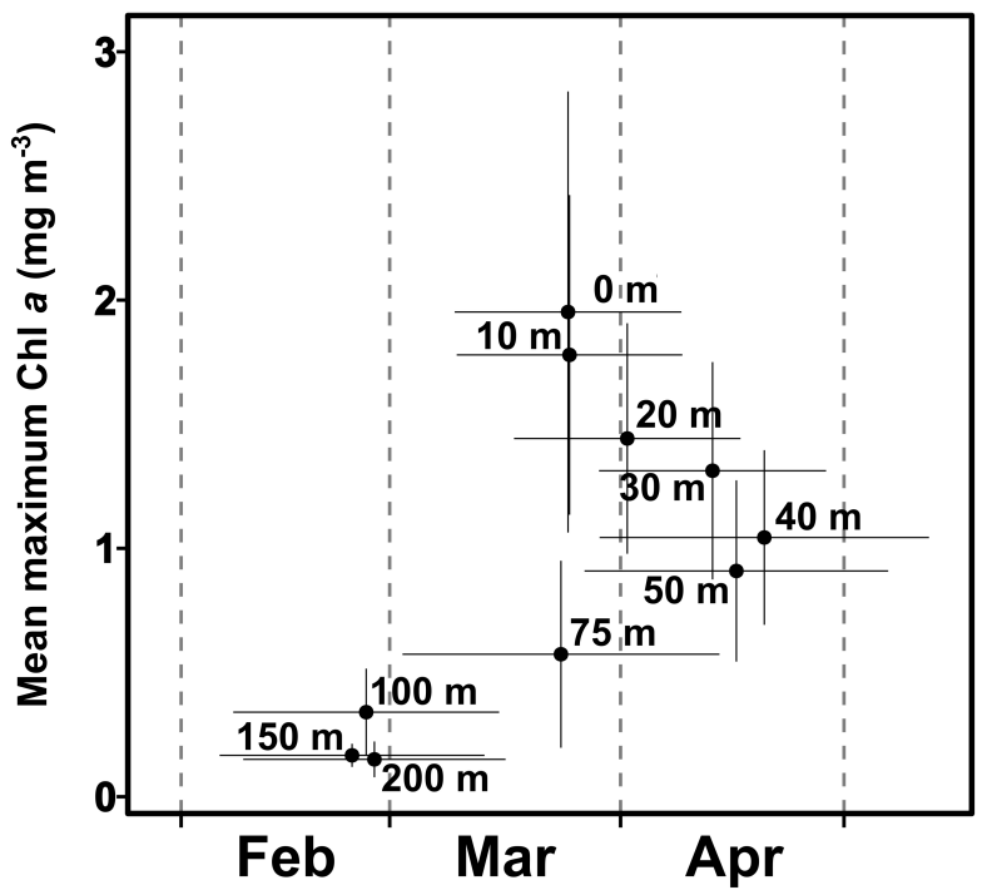

Fig. 4. Mean maximum $\mathrm{Chl} a$ concentration for each depth during the first half of the year and corresponding mean day of occurrence. Error bars indicate the $95 \%$ confidence interval. Months are delimited by vertical dashed lines.

This is the accepted version of the following article: González-Gil, R., González Taboada, F., Cáceres, C., Largier, J. L. and Anadón, R. (2017), Winter-mixing preconditioning of the spring phytoplankton bloom in the Bay of Biscay. Limnol. Oceanogr. doi:10.1002/Ino.10769, which has been published in final form at Limnology \& Oceanography. This article may be used for non-commercial purposes in accordance with the Wiley Self-Archiving Policy. 


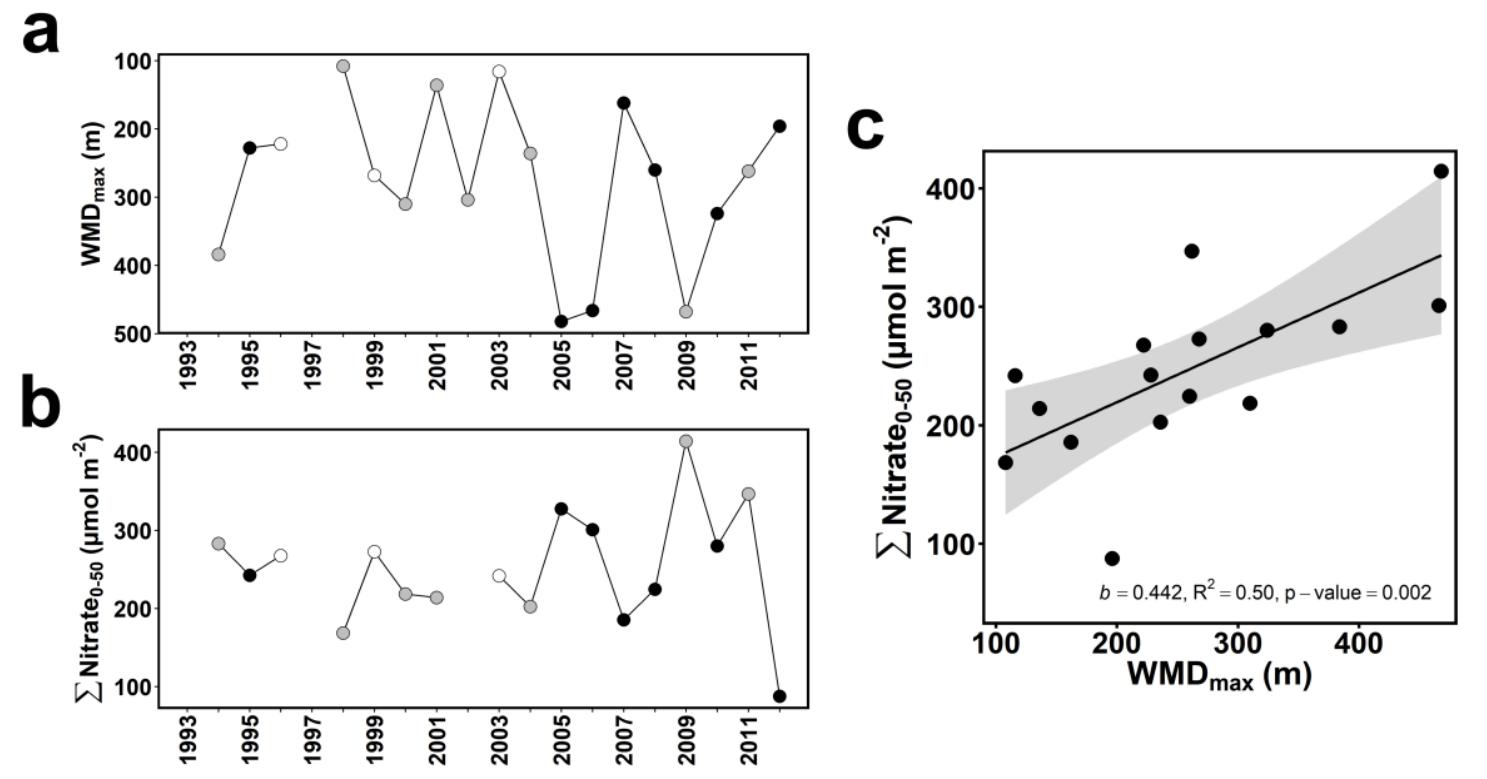

Fig. 5. Inter-annual variations of (a) maximum winter mixing depth $\left(\mathrm{WMD}_{\max }\right)$ and (b) depth-integrated nitrate $(0-50 \mathrm{~m}$, $\Sigma$ Nitrate $_{0-50}$ ) at the $\mathrm{WMD}_{\max }$ sampling date. Dot color represents the winter month when $\mathrm{WMD}_{\max }$ was measured (white, January; gray, February; black, March). (c) Linear relationship between $\Sigma$ Nitrate $_{0-50}$ at the $\mathrm{WMD}_{\max }$ sampling date and $\mathrm{WMD}_{\max }$. The shaded area represents the $95 \%$ confidence interval associated to the linear correlation. The slope $(b)$, proportion of variance explained $\left(\mathrm{R}^{2}\right)$ and $\mathrm{p}$-value of the relationship are shown.

This is the accepted version of the following article: González-Gil, R., González Taboada, F., Cáceres, C., Largier, J. L. and Anadón, R. (2017), Winter-mixing preconditioning of the spring phytoplankton bloom in the Bay of Biscay. Limnol. Oceanogr. doi:10.1002/Ino.10769, which has been published in final form at Limnology \& Oceanography. This article may be used for non-commercial purposes in accordance with the Wiley Self-Archiving Policy. 


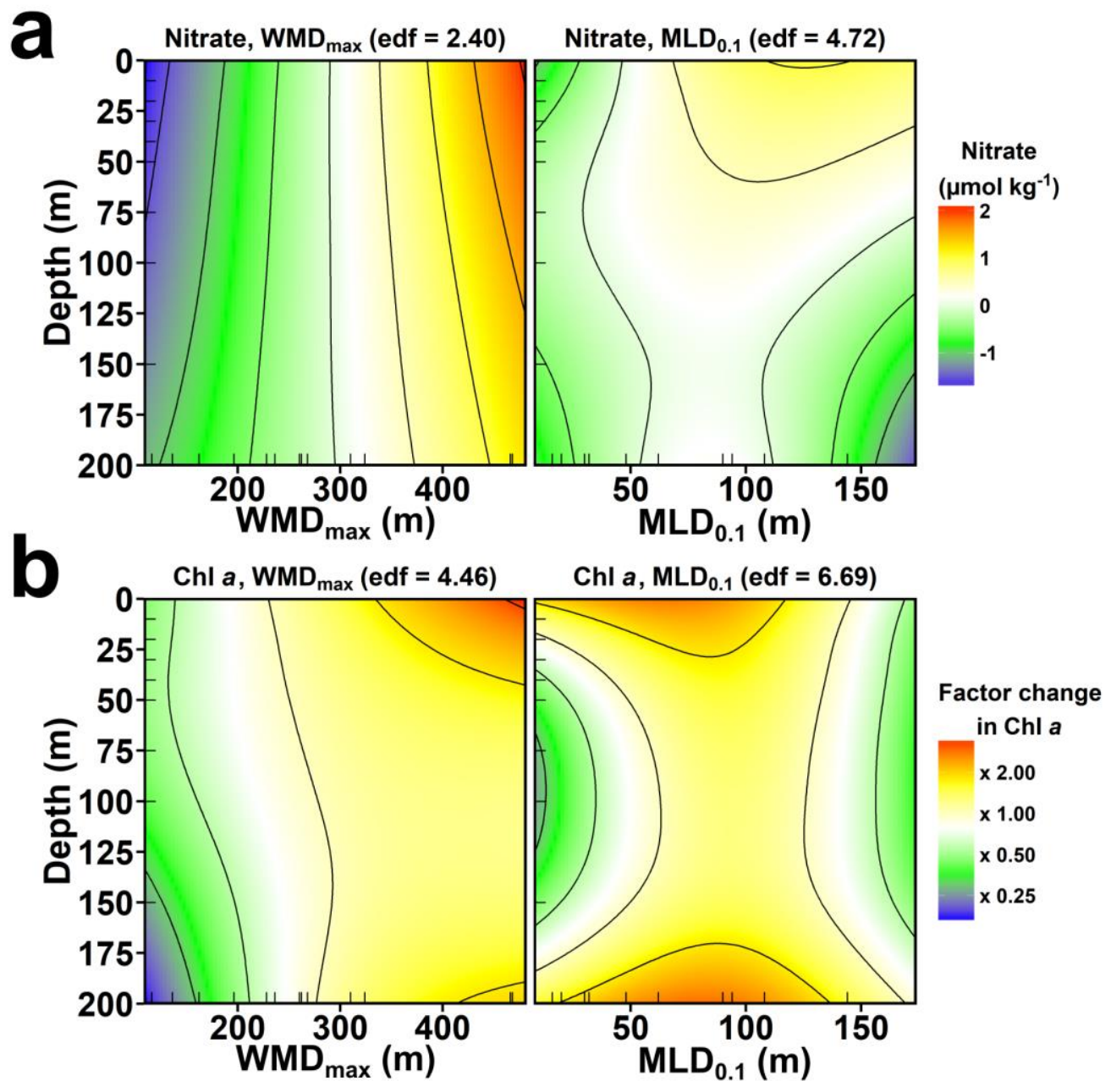

Fig. 6. Predicted (a) additive effects on nitrate concentration and (b) multiplicative effects on Chl $a$ concentration of both maximum winter mixing depth $\left(\mathrm{WMD}_{\max }\right)$ and near-surface stratification $\left(\mathrm{MLD}_{0.1}\right)$ in March. These values were obtained based on the best generalized additive model (GAM) of a set of proposed models to explore the effect of $\mathrm{WMD}_{\max }$ and $\mathrm{MLD}_{0.1}$ on nitrate and Chl $a$ concentrations (see Table 1). All terms in the model had a p-value $<0.010$ or $<0.050$ for nitrate and Chl $a$ concentration, respectively. The estimated degrees of freedom (edf) are also shown. The inner tick marks on each axis indicate where data were available.

This is the accepted version of the following article: González-Gil, R., González Taboada, F., Cáceres, C., Largier, J. L. and Anadón, R. (2017), Winter-mixing preconditioning of the spring phytoplankton bloom in the Bay of Biscay. Limnol. Oceanogr. doi:10.1002/Ino.10769, which has been published in final form at Limnology \& Oceanography. This article may be used for non-commercial purposes in accordance with the Wiley Self-Archiving Policy. 


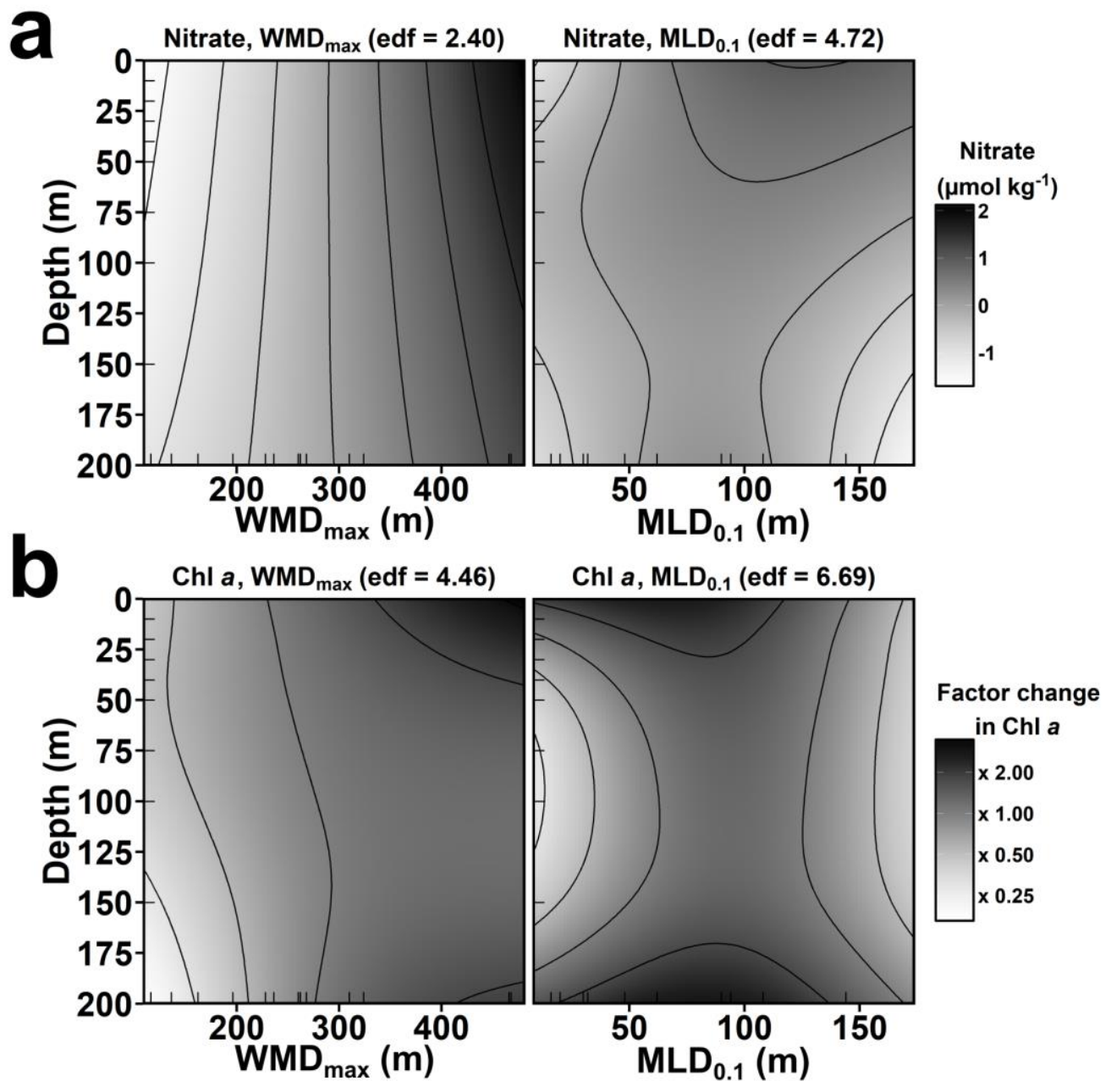

Fig. 6 (b/w). Predicted (a) additive effects on nitrate concentration and (b) multiplicative effects on Chl $a$ concentration of both maximum winter mixing depth $\left(\mathrm{WMD}_{\max }\right)$ and near-surface stratification $\left(\mathrm{MLD}_{0.1}\right)$ in March. These values were obtained based on the best generalized additive model (GAM) of a set of proposed models to explore the effect of $\mathrm{WMD}_{\max } \operatorname{and~}_{\mathrm{MLD}} \mathrm{D}_{0.1}$ on nitrate and Chl $a$ concentrations (see Table 1). All terms in the model had a p-value $<0.010$ or $<0.050$ for nitrate and Chl $a$ concentration, respectively. The estimated degrees of freedom (edf) are also shown. The inner tick marks on each axis indicate where data were available.

This is the accepted version of the following article: González-Gil, R., González Taboada, F., Cáceres, C., Largier, J. L. and Anadón, R. (2017), Winter-mixing preconditioning of the spring phytoplankton bloom in the Bay of Biscay. Limnol. Oceanogr. doi:10.1002/Ino.10769, which has been published in final form at Limnology \& Oceanography. This article may be used for non-commercial purposes in accordance with the Wiley Self-Archiving Policy. 

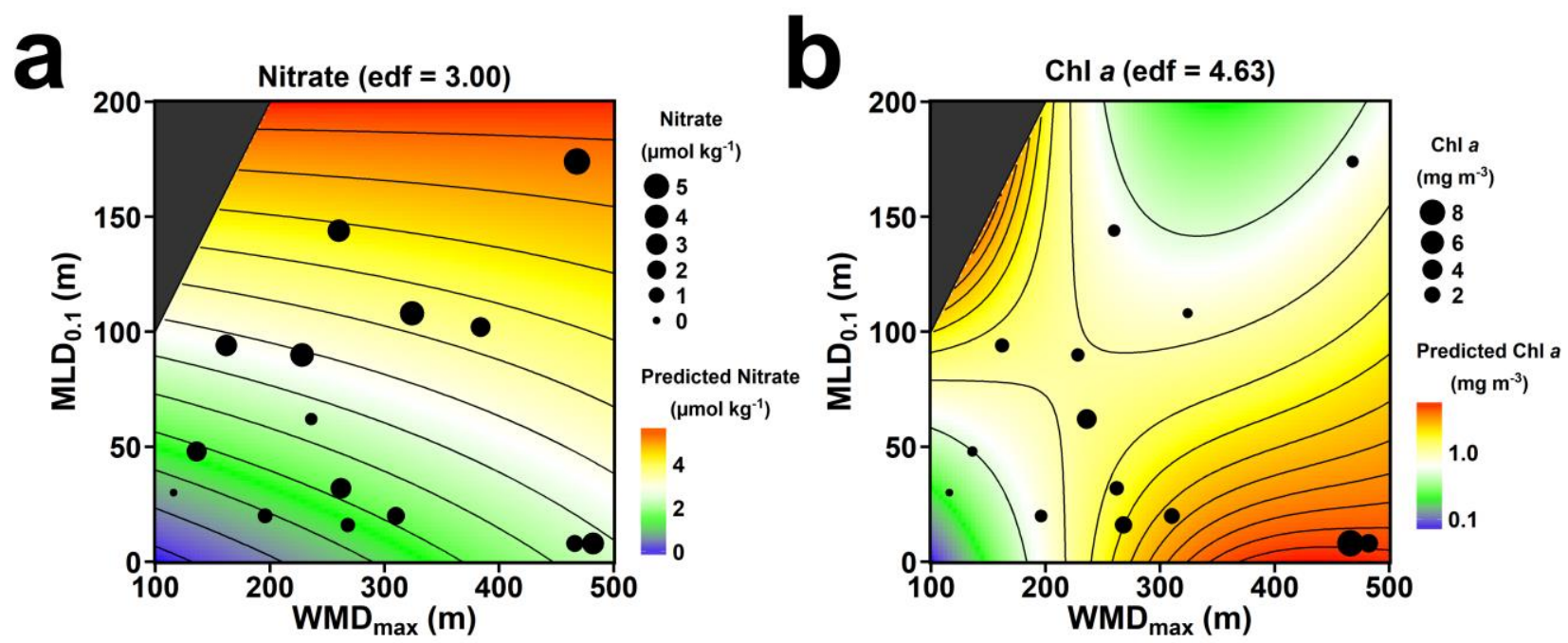

Fig. 7. Observed (dot size) and predicted (contour plot) concentrations of (a) nitrate and (b) Chl $a$ at surface ( $0 \mathrm{~m}$ depth) in March. Predicted values were obtained based on the generalized additive model (GAM) in Table 2 that included an interaction term between the maximum winter mixing depth $\left(\mathrm{WMD}_{\max }\right)$ and the near-surface stratification depth $\left(\mathrm{MLD}_{0.1}\right)$ in March. This interaction term had a p-value $<0.010$ or $<0.050$ for nitrate and Chl $a$ concentration, respectively. The estimated degrees of freedom (edf) for each model are indicated. The dark gray triangles on the top left corners delimit those combinations of $\mathrm{WMD}_{\max }$ and $\mathrm{MLD}_{0.1}$ that are not possible $\left(\mathrm{WMD}_{\max }\right.$ cannot be shallower than $\mathrm{MLD}_{0.1}$ ). Note that predicted Chl $a$ concentrations are shown in $\log _{10}$ scale.

This is the accepted version of the following article: González-Gil, R., González Taboada, F., Cáceres, C., Largier, J. L. and Anadón, R. (2017), Winter-mixing preconditioning of the spring phytoplankton bloom in the Bay of Biscay. Limnol. Oceanogr. doi:10.1002/Ino.10769, which has been published in final form at Limnology \& Oceanography. This article may be used for non-commercial purposes in accordance with the Wiley Self-Archiving Policy. 

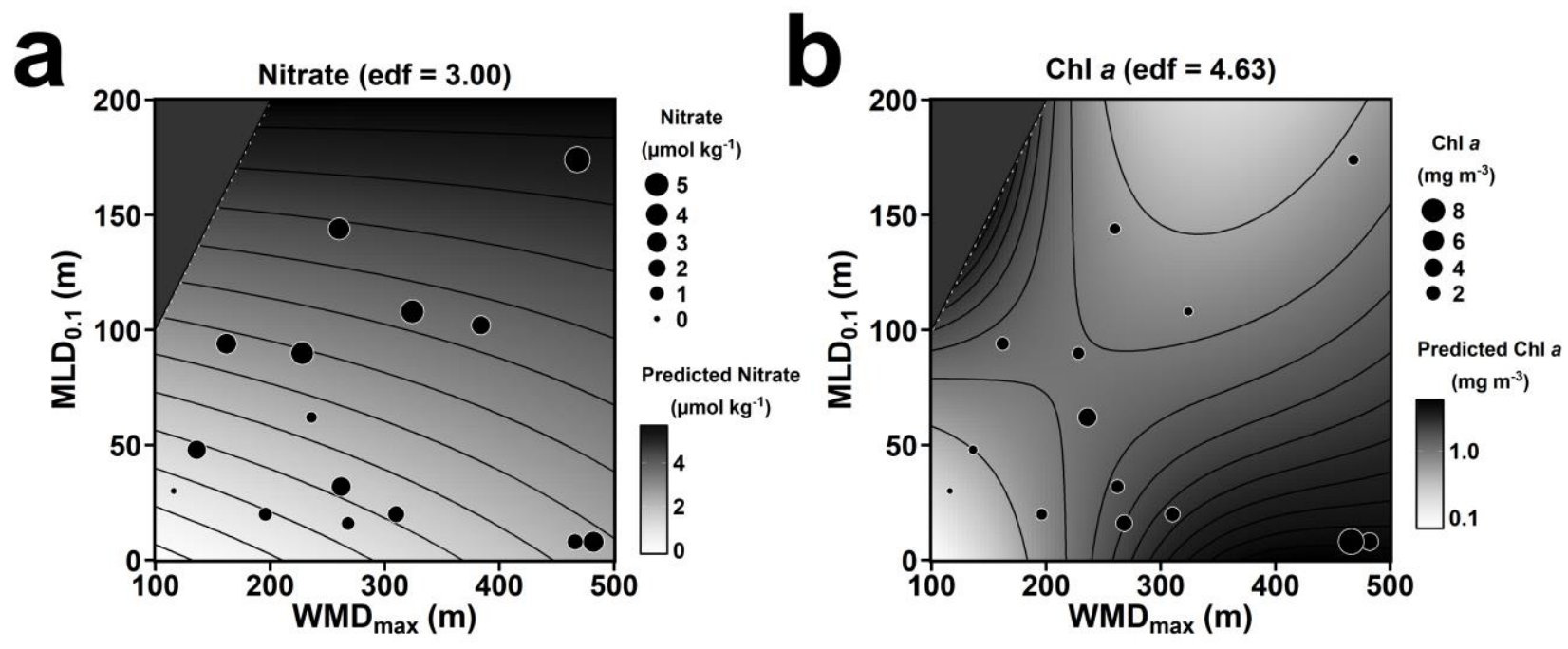

Fig. 7 (b/w). Observed (dot size) and predicted (contour plot) concentrations of (a) nitrate and (b) Chl $a$ at surface ( $0 \mathrm{~m}$ depth) in March. Predicted values were obtained based on the generalized additive model (GAM) in Table 2 that included an interaction term between the maximum winter mixing depth $\left(\mathrm{WMD}_{\max }\right)$ and the near-surface stratification depth (MLD 0.1$)$ in March. This interaction term had a p-value $<0.010$ or $<0.050$ for nitrate and $\mathrm{Chl} a$ concentration, respectively. The estimated degrees of freedom (edf) for each model are indicated. The dark gray triangles on the top left corners delimit those combinations of WMD $\mathrm{max}_{\operatorname{man}} \mathrm{MLD}_{0.1}$ that are not possible $\left(\mathrm{WMD}_{\max }\right.$ cannot be shallower than $\left.\mathrm{MLD}_{0.1}\right)$. Note that predicted Chl $a$ concentrations are shown in $\log _{10}$ scale.

This is the accepted version of the following article: González-Gil, R., González Taboada, F., Cáceres, C., Largier, J. L. and Anadón, R. (2017), Winter-mixing preconditioning of the spring phytoplankton bloom in the Bay of Biscay. Limnol. Oceanogr. doi:10.1002/Ino.10769, which has been published in final form at Limnology \& Oceanography. This article may be used for non-commercial purposes in accordance with the Wiley Self-Archiving Policy. 


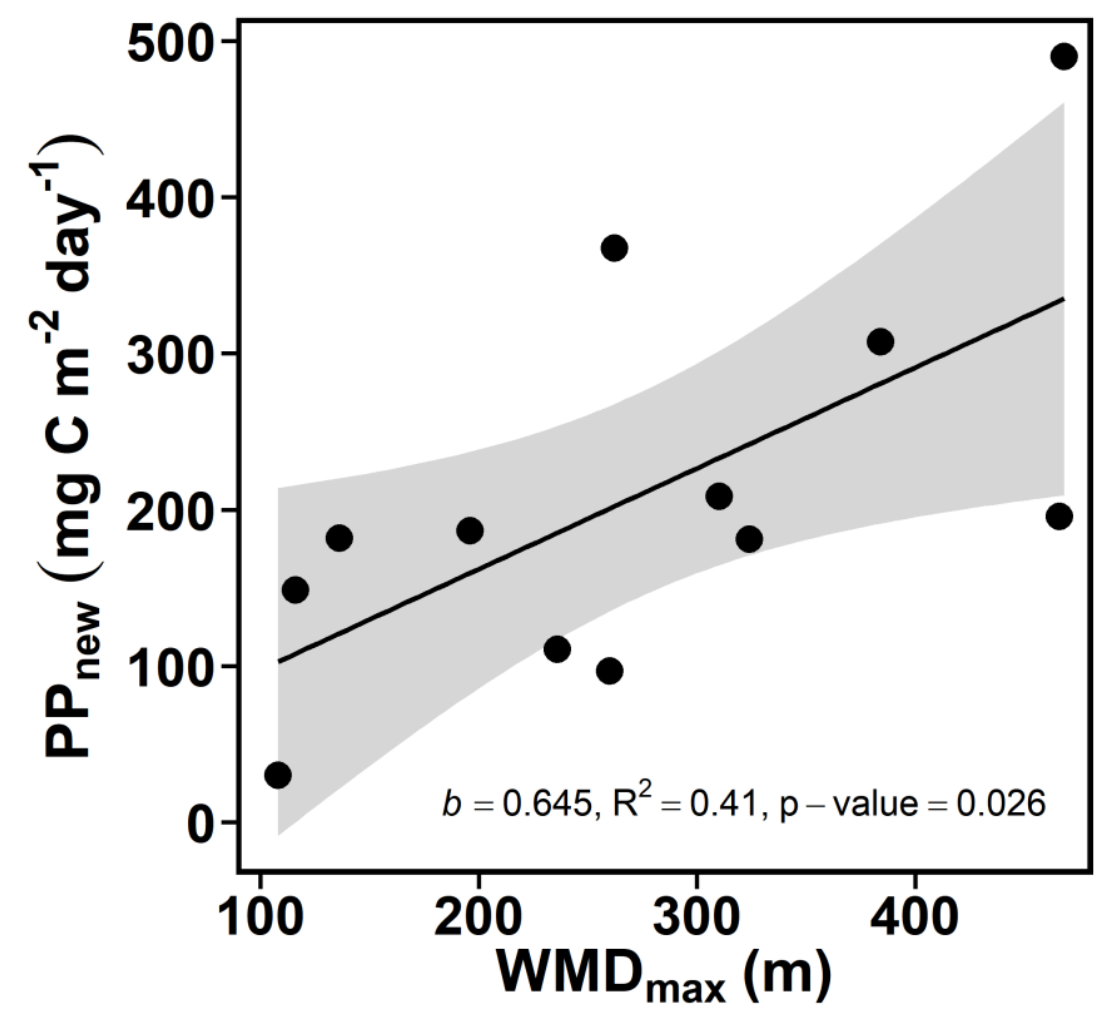

Fig. 8. Linear relationship between the new primary production $\left(\mathrm{PP}_{\text {new }}\right)$ in the upper $50 \mathrm{~m}$ of the water column between

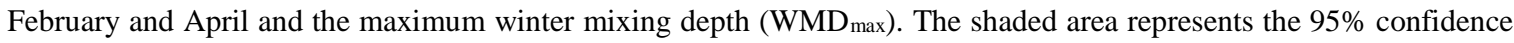
interval associated with the linear correlation. The slope $(b)$, proportion of variance explained $\left(\mathrm{R}^{2}\right)$ and $\mathrm{p}$-value of the relationship are shown.

This is the accepted version of the following article: González-Gil, R., González Taboada, F., Cáceres, C., Largier, J. L. and Anadón, R. (2017), Winter-mixing preconditioning of the spring phytoplankton bloom in the Bay of Biscay. Limnol. Oceanogr. doi:10.1002/Ino.10769, which has been published in final form at Limnology \& Oceanography. This article may be used for non-commercial purposes in accordance with the Wiley Self-Archiving Policy. 

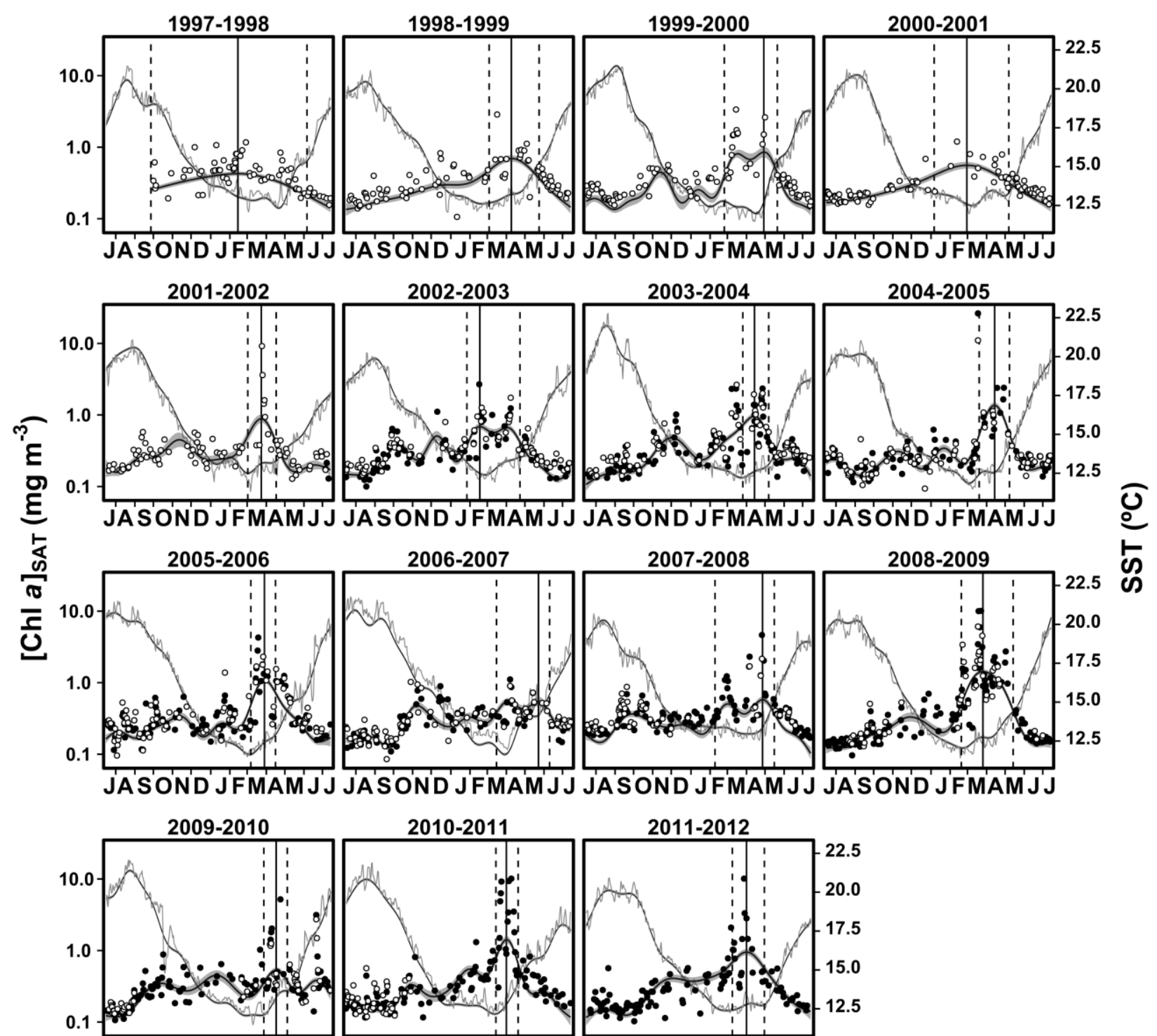

JASOND J'MAM JJ JASOND JFMAM J'J JASOND JFMAM JJ

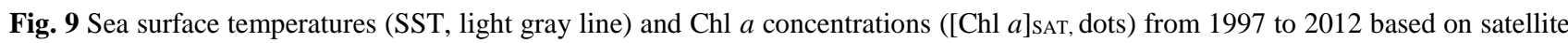
retrievals. Dot color indicates the sensor used to get the [Chl a]sAT measurements (white for SeaWifs and black for Aqua MODIS). Estimated seasonal cycles for SST (dark gray line) and $[\mathrm{Chl} a]_{\mathrm{SAT}}$ (black line) and their associated $95 \%$ confidence intervals (shaded areas) are based on the generalized additive model (GAM) predictions. The estimated degrees of freedom (edf) of the model varied between 16.19 and 18.53 for SST or between 3.19 and 13.42 for $[\mathrm{Chl} a]_{\mathrm{SAT}}$. Vertical solid lines indicate the maximum estimated $[\mathrm{Chl} a]_{\mathrm{SAT}}$ during the spring bloom. The initiation and termination day of the spring bloom are marked with vertical dashed lines. Note that $[\mathrm{Chl} a]_{\mathrm{SAT}}$ is shown in $\log _{10}$ scale and that the beginning of the seasonal cycle is set to July $15^{\text {th }}$ (or $14^{\text {th }}$ in a leap year).

This is the accepted version of the following article: González-Gil, R., González Taboada, F., Cáceres, C., Largier, J. L. and Anadón, R. (2017), Winter-mixing preconditioning of the spring phytoplankton bloom in the Bay of Biscay. Limnol. Oceanogr. doi:10.1002/Ino.10769, which has been published in final form at Limnology \& Oceanography. This article may be used for non-commercial purposes in accordance with the Wiley Self-Archiving Policy. 


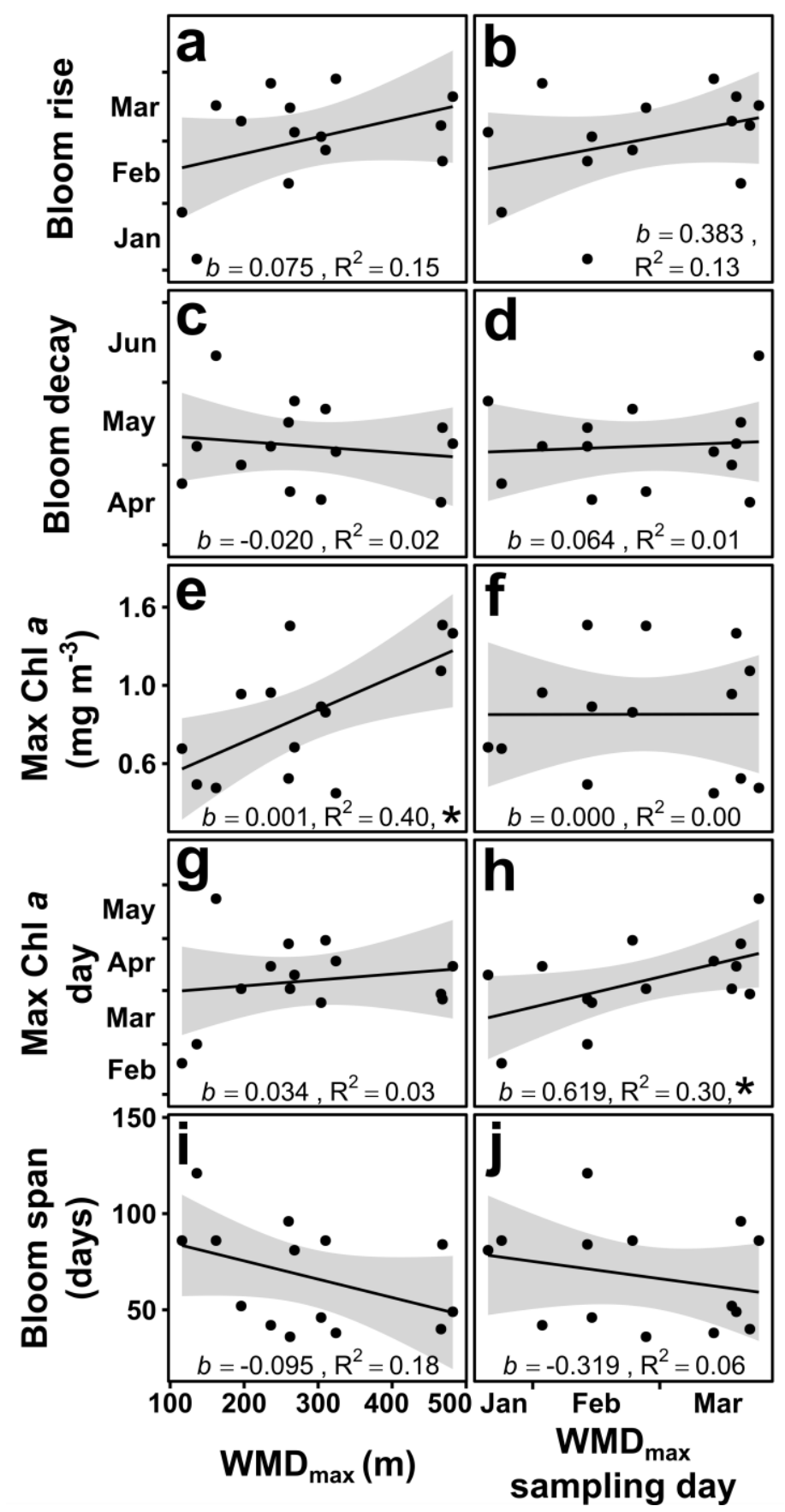

Fig. 10. Impact of the intensity and timing of the maximum winter mixing depth (WMD ${ }_{\max }$ and $\mathrm{WMD}_{\max }$ sampling date, respectively) on spring bloom metrics: (a-b) bloom rise, (c-d) bloom decay, (e-f) max Chl $a$, (g-h) max Chl $a$ timing and (i-j) bloom span. The spring bloom metrics were derived from a generalized additive model (GAM) based on satellite data. The shaded areas associated with each linear relationship depict the $95 \%$ confidence intervals. The slope $(b)$ and proportion of variance explained $\left(\mathrm{R}^{2}\right)$ of each relationship are shown. Those linear regressions with a p-value $<0.050$ are indicated with a*. Note that max Chl $a$ is shown in $\log _{10}$ scale.

This is the accepted version of the following article: González-Gil, R., González Taboada, F., Cáceres, C., Largier, J. L. and Anadón, R. (2017), Winter-mixing preconditioning of the spring phytoplankton bloom in the Bay of Biscay. Limnol. Oceanogr. doi:10.1002/Ino.10769, which has been published in final form at Limnology \& Oceanography. This article may be used for non-commercial purposes in accordance with the Wiley Self-Archiving Policy. 
a

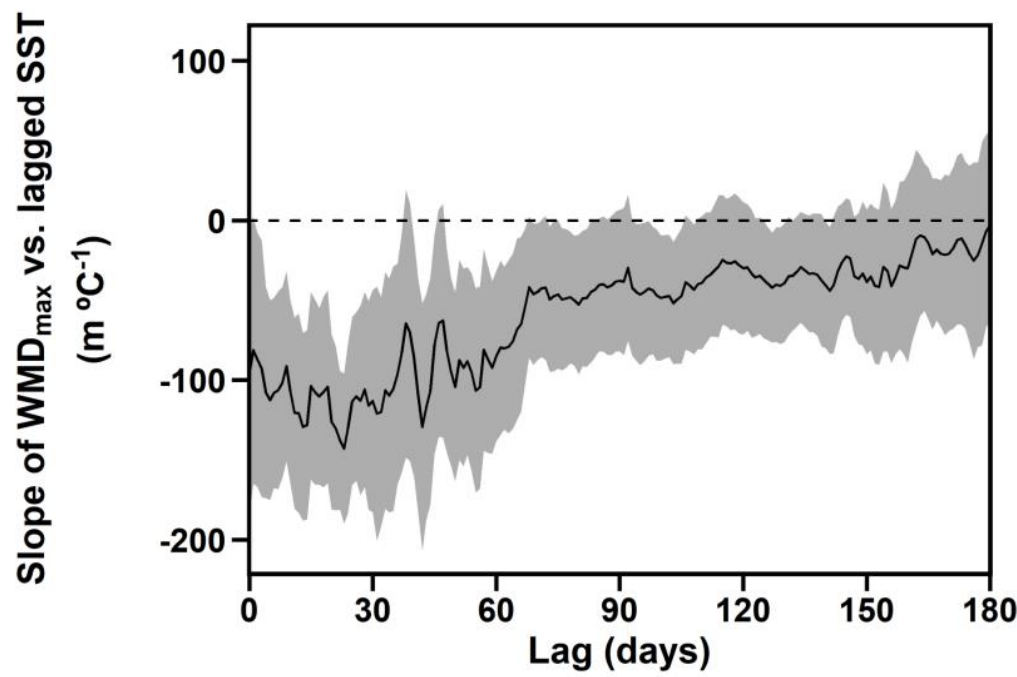

b

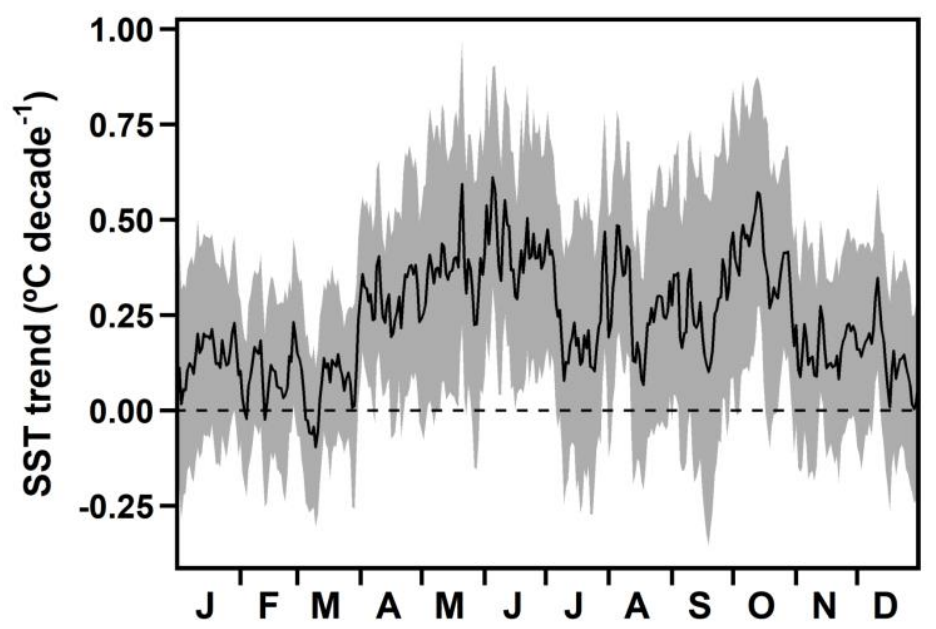

Fig. 11. (a) Variations in the slope of the linear relationships between maximum winter mixing depth (WMD $\mathrm{max})$ and the Sea Surface Temperature (SST) based on satellite retrievals at different day lags (1993-2012). (b) Long-term linear trends in SST (1981-2012) for each day of the year. Dashed horizontal lines indicate zero values. Shaded areas depict the $95 \%$ confidence intervals associated with the regression slopes.

This is the accepted version of the following article: González-Gil, R., González Taboada, F., Cáceres, C., Largier, J. L. and Anadón, R. (2017), Winter-mixing preconditioning of the spring phytoplankton bloom in the Bay of Biscay. Limnol. Oceanogr. doi:10.1002/Ino.10769, which has been published in final form at Limnology \& Oceanography. This article may be used for non-commercial purposes in accordance with the Wiley Self-Archiving Policy. 
Table 1. Results from the model selection for the assessment of the effect of winter mixing depth (WMD ${ }_{\max }$ ) and our proxy for the thickness of the surface stratified layer $\left(\mathrm{MLD}_{0.1}\right)$ on nitrate and Chl $a$ concentration at all depths (both represented as $y$ in the formulas) in March. All models included an intercept $(a)$ and an error term $(\varepsilon)$. In addition, the generalized additive models (GAMs) incorporated through a smooth function $(f$, see Supporting information for further details) the influence of depth $(z)$, or also the effect of the interaction $($ te $)$ between $\mathrm{MLD}_{0.1}$ or $\mathrm{WMD}_{\mathrm{max}}$ and proportion of variance explained $\left(\mathrm{R}^{2}\right)$. In all cases, the overall model had a $\mathrm{p}$-value $<0.001$.

\begin{tabular}{|c|c|c|c|c|c|c|c|}
\hline \multirow[b]{2}{*}{ Model } & \multirow[b]{2}{*}{ What does the model estimate? } & \multicolumn{3}{|c|}{ Nitrate } & \multicolumn{3}{|c|}{ Chl $a$} \\
\hline & & AIC & $\begin{array}{c}\text { AIC } \\
\text { weight }\end{array}$ & $\mathbf{R}^{2}$ & AIC & $\begin{array}{c}\text { AIC } \\
\text { weight }\end{array}$ & $\mathbf{R}^{2}$ \\
\hline$y=a+\varepsilon$ & Null model (includes only an intercept). & 598.80 & 0.00 & 0.00 & 222.61 & 0.00 & 0.00 \\
\hline$y=a+f(z)+\varepsilon$ & Effect of depth. & 534.20 & 0.00 & 0.36 & 139.50 & 0.00 & 0.47 \\
\hline$y=a+f(z)+t e\left(W M D_{\max }, z\right)+\varepsilon$ & $\begin{array}{l}\text { Effect of winter mixing through the water column while } \\
\text { accounting for the influence of depth. }\end{array}$ & 452.09 & 0.00 & 0.64 & 122.99 & 0.00 & 0.56 \\
\hline$y=a+f(z)+t e\left(M L D_{0.1}, z\right)+\varepsilon$ & $\begin{array}{l}\text { Effect of stratification through the water column while } \\
\text { accounting for the influence of depth. }\end{array}$ & 513.04 & 0.00 & 0.48 & 131.77 & 0.00 & 0.54 \\
\hline$y=a+f(z)+t e\left(M L D_{0.1}, z\right)+t e\left(W M D_{\max }, z\right)+\varepsilon$ & $\begin{array}{l}\text { Combined effect of stratification and winter mixing through } \\
\text { the water column while accounting for the influence of depth. }\end{array}$ & 419.50 & 1.00 & 0.73 & 101.29 & 1.00 & 0.65 \\
\hline
\end{tabular}

This is the accepted version of the following article: González-Gil, R., González Taboada, F., Cáceres, C., Largier, J. L. and Anadón, R. (2017), Winter-mixing preconditioning of the spring phytoplankton bloom in the Bay of Biscay. Limnol. Oceanogr. doi:10.1002/Ino.10769, which has been published in final form at Limnology \& Oceanography. This article may be used for non-commercial purposes in accordance with the Wiley Self-Archiving Policy. 


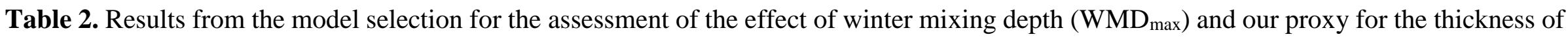
917 the surface stratified layer $\left(\mathrm{MLD}_{0.1}\right)$ on nitrate and Chl $a$ concentration (both represented as $y$ in the formulas) at the surface ( $0 \mathrm{~m}$ depth) in March.

918 All models included an intercept $(a)$ and an error term $(\varepsilon)$. In addition, the generalized additive models (GAMs) incorporated a smooth function $(f$ 919 see Supporting information for further details) to estimate the effect of $\mathrm{WMD}_{\max }, \mathrm{MLD}_{0.1}$ or their interaction (te, last model). We report for each 920 model the Akaike Information Criterion (AIC) and its associated weight (Burnham and Anderson 2002), and the proportion of variance explained $921\left(\mathrm{R}^{2}\right)$. The $\mathrm{p}$-values for the overall model are also shown.

\begin{tabular}{|c|c|c|c|c|c|c|c|c|c|}
\hline \multirow[b]{2}{*}{ Model } & \multirow[b]{2}{*}{ What does the model estimate? } & \multicolumn{4}{|c|}{ Nitrate } & \multicolumn{4}{|c|}{ Chl $a$} \\
\hline & & AIC & $\begin{array}{c}\text { AIC } \\
\text { weight }\end{array}$ & $\mathbf{R}^{2}$ & p-value & AIC & $\begin{array}{c}\text { AIC } \\
\text { weight }\end{array}$ & $\mathbf{R}^{2}$ & p-value \\
\hline$y=a+\varepsilon$ & Null model (includes only an intercept). & 60.63 & 0.00 & 0.00 & 0.000 & 20.12 & 0.00 & 0.00 & 0.572 \\
\hline$y=a+f\left(W M D_{\max }\right)+\varepsilon$ & Effect of winter mixing. & 59.92 & 0.00 & 0.17 & 0.132 & 17.42 & 0.02 & 0.29 & 0.049 \\
\hline$y=a+\left(M L D_{0.1}\right)+\varepsilon$ & Effect of stratification. & 51.51 & 0.21 & 0.52 & 0.002 & 19.78 & 0.01 & 0.15 & 0.165 \\
\hline$y=a+f\left(M L D_{0.1}\right)+f\left(W M D_{\max }\right)+\varepsilon$ & $\begin{array}{l}\text { Independent combined effect of stratification and winter } \\
\text { mixing. }\end{array}$ & 49.70 & 0.53 & 0.63 & 0.003 & 15.14 & 0.06 & 0.48 & 0.030 \\
\hline$y=a+t e\left(W M D_{\max }, M L D_{0.1}\right)+\varepsilon$ & $\begin{array}{l}\text { Interactive combined effect of winter mixing and } \\
\text { stratification. }\end{array}$ & 51.16 & 0.26 & 0.64 & 0.008 & 9.72 & 0.91 & 0.75 & 0.016 \\
\hline
\end{tabular}

